\title{
LA GOVERNACIÓ AL PRINCIPAT DE CATALUNYA I ALS COMTATS DE ROSSELLÓ I CERDANYA
}

\author{
Flocel SABATÉ i CURULL
}

\begin{abstract}
A Catalunya, entre els segles XIII i XV, s'articula l'alta delegació del sobirà, veritable reflex de la consolidació de la posició reial i catalitzadora de les tensions entre els vectors de poder. La figura es mostra com elevada magistratura d'un país cohesionat per la pròpia sinergia dels diferents grups de pressió, entre els quals evolucionarà fins a sortir dels temps medievals amb una posició afermada però, alhora, ja desplaçada de destacades preeminències. El recorregut per aquesta institució, doncs, transporta la consolidació reial entre l'emergència municipal i la puixança baronial a través de les llums i foscors dels segles que clouen l'edat mitjana'.
\end{abstract}

\section{VERS L'ALTA REPRESENTACIÓ REIAL PERMANENT}

Minoria d'edat, delegacions sobre àmbits territorials específics, designacions entorn de problemàtiques concretes, cura de la posició de l'hereu i representacions plenàries en afers públics i privats basteixen la deslligada successió de procuracions inorgàniques sota Jaume I que la historiografia ha assenyalat com a punt d'endegament de l'alta

1 Abreviatures emprades: ACA, Arxiu de la Corona d'Aragó; ACP, Archives Communales de Perpignan; ACV, Arxiu Capitular de Vic; ADPO, Archives Départementales des Pyrénées-Orientales; AHCBa, Arxiu Històric de la Ciutat de Barcelona; AHCBE, Arxiu Històric Comarcal de la Bisbal d'Empordà; $\mathrm{AHCBe}$, Arxiu Històric Comarcal de Berga; AHCC, Arxiu Històric Comarcal de Cervera; AHCG, Arxiu Històric de la Ciutat de Girona; $A H C l$, Arxiu Històric Comarcal d'lgualada; AHCO, Arxiu Històric Comarcal d'Olot; AHCP, Arxiu Històric Comarcal de Puigcerdà; AHCR, Arxiu Històric Comarcal de Reus; AHCT, Arxiu Històric Comarcal de Tàrrega; AHCTE, Arxiu Històric Comarcal de les Terres de l'Ebre; AHCV, Arxiu Històric Comarcal de Valls; AHMV, Arxiu Històric Municipal de Vic; AHMTM, Arxiu Històric Municipal de Torroella de Montgrí; AHPB, Arxiu Històric de Protocols de Barcelona; AHS, Arxiu Històric de Sabadell; AMC, Arxiu Municipal de Camprodon; AML, Arxiu Municipal de Lleida; AVV, Arxiu del Veguer de Vic; CF, Arxiu de la Curia Fumada de Vic. 
representació del sobirà ${ }^{2}$, bé que encara en un estadi força inicial $\mathrm{i}$, per això mateix, amb una posició poc definida ${ }^{3}$. En aquests moments, la procuració en l'àmbit reial concorda amb delegacions similars en altres cases nobiliàries, com en l'emblemàtic cas d'Urgell4, alhora que participa de la consolidació del casal de Barcelona sobre un conjunt català que va desenvolupant unes comunes institucions i legislacions ${ }^{5}$. S'hi apleguen tant les línies de cohesió interna dels respectius territoris constitutius de la corona com l'afany del sobirà per afermar el propi poder i, a la vegada, garantir la posició dels fills. La delegació permanent es manté des que el 1257 el primogènit Pere rep la procurationem et regimen totum ab integro totius Catalonie a Salses, videlicet usque in Cinquam ${ }^{6}$. Poc després, el 1261, el secundogènit Jaume pot presentar-se com a habentes vicem et locum domini regis patris nostri in negocio feudorum in Rossilione, Ceritania et Confluenti?. En ambdós casos, la delegació reial prepara la succesió del monarca pels seus fills, com es materialitza en la partió sorgida a la mort de Jaume I el $1276^{\circ}$.

La funció és continuada per Pere II sota la figura de la lloctinència reial exercida pel primogènit Alfons, amb la plenitud de potestat sobre la corona, necessària, a més, per raó de les absències reials del país. En aquests moments, l'administració del monarca incorpora la figura del batlle genera ${ }^{9}$, singularitza la tresoreria ${ }^{10}$, tempteja el

2 Jesús LALINDE, La gobernación general en la Corona de Aragón, Institución «Fernando el Católico", Zaragoza, 1963, pp. 3-40; Ferran SOLDEVILA, Jaume I. Pere el Gran, Edicions Vicens Vives, Barcelona, 1985, pp. 43-44; Ferran SOLDEVILA, Pere el Gran, Institut d'Estudis Catalans, Barcelona, 1995, pp. 35-37.

3 En importancia son muy inferiores a un mayordomo o a un senescal, aunque eso sí, representan la administración joven y del futuro, mientras que la otra, replegada en sí, camina hacia su anquilosamiento (Jesús LALINDE, El ordenamiento interno de la Corona de Aragón en la época de Jaime I, «X Congreso de Historia de la Corona de Aragón (Zaragoza, 1979)», Zaragoza, 1980, vol. I, p. 192).

4 Flocel SABATE, Organització territorial i administrativa del comtat d"Urgell, «El Comtat d'Urgell», Edicions de la Universitat de Lleida-Institut d'Estudis llerdencs, Lleida, 1995, p. 66.

5 Flocel SABATÉ, El territori de la Catalunya medieval. Percepció de l'espai i divisió territorial al llarg de l'Edat Mitjana, Fundació Salvador Vives Casajuana, Barcelona, 1997, pp. 277-280.

6 ACA, Cancelleria, pergamins de Jaume I, núm. (ed.: Antonio $\mathrm{HUICl,} \mathrm{Colección} \mathrm{Diplomática} \mathrm{de}$ Jaime I el Conquistador, II, La Voz Valenciana, València, 1919, pp. 92-93).

7 B. ALART, Privilèges et titres relatifs aux franchises, institutions et propiétés communales de Roussillon et de Cerdagne depuis le Xle siècle jusqu'à l'an 1660, Charles Labtrobe, imprimeur-libraire, Perpignan, 1874, p. 249.

8 ACA, Cancelleria, pergamins de Jaume I, núm. 1720; Cancelleria, reg. 310. fol. 584r-v (ed.: Antonio HUICl, Colección Diplomática de Jaime l el Conquistador, III, Renovación Tipográfica Valenciana, Valencia, 1922, pp. 165-166).

9 Tomàs de MONTAGUT, El baile general de Cataluña (notas para su estudio), "Hacienda Pública Española», 87 (Madrid, 1984), p. 74.

10 David ROMANO, El judío Jucef Ravaya, tesorero real, en la ocupación de Sicilia (fines de 1282), "XI Congresso di Storia della Corona d'Aragona (Palermo-Trapani-Erice, 1982)", vol. IV, Accademia di Scienze, lettere e arti, Palermo, 1984, pp. 151-152; David ROMANO, Los funcionarios judíos de Pedro el Grande de Aragón, "Boletín de la Real Academia de Buenas Letras de Barcelona", XXXIII (Barcelona, 1969-1970), p. 12. 
mestre racional ${ }^{11} \mathrm{i}$ continua perfilant l'ordenament de la cancelleria ${ }^{12}$, alhora que endreça la casa reial ${ }^{13}$. Enllaçant amb aquesta dinàmica, Alfons el Lliberal (1286-1291) reprèn la delegació permanent i específica sobre el conjunt de Catalunya, primer designada com a procuració i després, coincidint amb el seu exercici dins de la família reial, oscil.lant entre lloctinència i vicegerència. En el context d'una monarquia que cerca signes de preeminència sobre el conjunt territorial, el primer receptor de l'ofici és el mateix comte de Pallars que coetàniament el sobirà vol estretir amb la corona ${ }^{14}$, mentre que el fet de ser succeït per l'infant Pere renova la posició de la família reial en l'ofici més proper al monarca, alhora que referma la unitat de tractament de la corona en mantenir en el mateix infant la procuració sobre Aragó que ja desenvolupava prèviament ${ }^{15}$.

Amb Jaume II es reprèn el tractament específic de Cataiunya sota un procurador reial, que breument és Albert de Mediona i tot seguit el vescomte de Cardona, que desenvolupa l'ofici fins el 1301. En aquest any, el monarca atorga la procuració general al primogènit Jaume malgrat la seva escassa edat ${ }^{16}$. Es palesa així la identificació de l'ofici delegat amb el successor al tron, alhora que l'operativitat s'aconsegueix en designar un vicegerent específic per a Catalunya ${ }^{17}$.

Entre 1303 i 1304 Jaume II assaja la fórmula de les supravegueries, consistent en descentralitzar el poder reial en benefici de quatre supraveguers, amb seu a Barcelona, Lleida, Girona i Tortosa, que actuaran loco et vice procuratoribus nostri, en paraules del monarca ${ }^{18}$, al designar els representants territorials reials --veguers i sotsveguers-, rebre apel.lacions $i$ atendre els problemes de govern. En comptes d'agilitar la cancelleria reial com es pretenia, aviat es constata que l'administració s'ha complicat amb un nivell més, sense aconseguir limitar l'accés dels diferents grups al monarca, requerint una obligada intervenció de la cort reial en els afers considerats greus $\mathrm{i}$ evidenciant, en definitiva, les incapacitats dels supraveguers tant per a voltarse d'oficials eficaços i combatre la corrupció com per a imposar-se en un entorn de

11 Tomàs DE MONTAGUT, El Mestre Racional a la Corona d'Aragó (1283-1419), I, Fundació Noguera, Barcelona, 1987, pp. 49-56.

12 J. TRENCHS y R. CONDE, Registros y registración bajo Pedro el Grande, «XI Congresso di Storia della Corona d'Aragona (Palermo-Trapani-Erice, 1982)", vol. IV, Accademia di Scienze, lettere e arti, Palermo, 1984, pp. 397-400.

13 Francesch CARRERAS i CANDI, Redreç de la reyal casa: ordenaments de Pere "lo Gran" e Anfós "lo Lliberal» (segle XIII), "Boletín de la Real Academia de Buenas Letras de Barcelona», IX/35 (Barcelona, 1909), pp. 97-105.

14 J. BAUCELLS i REIG, La successió dels comtes de Pallars en el dos-cents, "X Congreso de Historia de la Corona de Aragón (Zaragoza, 1979)", Comunicaciones 3,4 y 5, Institución Fernando el Católico, Zaragoza, 1980, pp. 36-37.

15 Inclito karisimo fratri suo infanti Petro procuratori Aragonum et in Cathalonie vices nostras gerenti (ACA, Cancelleria, reg. 77, fol. 21v).

16 Joaquim MIRET i SANS, El forassenyat primogènit de Jaume //, Institut d'Estudis Catalans, Barcelona, 1957, pp. 9-10.

17 ACA, Cancelleria, reg. 199, fols. $21 v$ i $71 r$.

18 ACA, Cancelleria, reg. 231 , fols. $57 \mathrm{v}, 67 \mathrm{r}$. 
capitalitats vicarials entre les que destaca la forta ingerència de les respectives seus municipals supravicarials ${ }^{19}$.

Es retorna a una atenció conjunta de Catalunya per part d'un vicegerent -que continuarà el tractament de la majoria dels afers deixats oberts pels antics supraveguers ${ }^{20}$ _- definit sota el procurador general coincident amb l'hereu del tron. El vicegerent esdevé col.laborador bàsic en la gestió reial sobre Catalunya, alhora que la procuració general es consolida com una delegació plena i no sols substitutòria, entesa, segons expressa Jaume II el 1321, com una permanent comissione generalis procuracionis regnorum et terrarum nostrorum ${ }^{21}$. El 1323 el sobirà accepta que el procurador general designi el seu gerens vices, en comptes de continuar fent-ho directament ${ }^{22}$, cosa, però que poc canvia perquè el dirigisme reial es garanteix ${ }^{23}$ sobre un ofici no sols ben consolidat en la percepció i gestió del país sinó desenvolupat per cavallers ben propers al monarca, sovint membres del seu consell.

Alfons III perllonga el mateix plantejament, amb el seu fill definit com a procurador general quan encara és menor i amb un tractament unitari de Catalunya que, després de ser ofert el 1327 a Guillem de Senesterra com a locumtenens procuratoris generalis ${ }^{24}$, reprèn la denominació de vicegerent, sota nomenament reial i amb una constant presència en el govern del país. La fixació del sistema el manté fins i tot quan al monarca no li plau. Per això, quan Pere III el 1336 enceta el regnat sense fills, ha de consentir com a procurador general el seu germà, el comte d'Urgell, tot mantenint la relació administrativa superior en el tractament ofert mitjançant la vicegerència.

L'alteració del sistema es pretén el 1344. En el context d'una reforma de la representació territorial en el conjunt de la Corona, Pere el Ceremoniós a partir de la xarxa vicarial divideix el conjunt català en tres governacions - Barcelona, Girona $i$ Lleida- descartant Tortosa per centrar, des de 1329, el marquesat de l'infant Ferran ${ }^{25}$. La plena delegació en els governadors, el desenvolupament sota d'aquests d'unes procuracions actives en la defensa del patrimoni reial $i$, sobretot, la ingerència governativa en les tasques jurisdiccionals $i$ en un exercici judicial que els municipis prefereixen en mans dels més mediatitzables oficials ordinaris, indisposen els poders locals contra la reforma. Aquesta també fracassa en no aconseguir una descentralització perquè tant els veguers com els diferents poders baronials i municipals continuen

19 Flocel SABATE, El territori de la Catalunya medieval. Percepció de l'espai i divisió territorial al llarg de l'Edat Mitjana, Fundació Salvador Vives Casajuana, Barcelona, 1997, pp. 324-327.

20 AHCT, pergamins, caixa 2, 1305; ACA, Cancelleria, reg. 235, fol. $133 \mathrm{v}$.

21 ACA, Cancelleria, reg. 233, fol. 7v.

22 ACA, Cancelleria, reg. 231, fol. 119r-v.

23 ACA, Cancelleria, reg. 233, fol. $23 v$ (ed.: Jesús LALINDE, La gobernación general en la Corona de Aragón, Institución «Fernando el Católico», Zaragoza, 1963, pp. 518-519).

24 Josefina MATEU IBARS, La delegación del poder real en Sicilia desde el reinado de Pedro III de Aragón. Sincronismos del «alter nos» en la Corona de Aragón durante los siglos XIII-XIV, «XI Congresso di Storia della Corona d'Aragona (Palermo, Trapani, Erice, 1982)", vol. 3, Accademia de Scienze, Lettere e arti, Palermo, 1983, p. 353.

25 ACA, Cancelleria, regs. 954, fol. 79 ; 979 , fol. 64 r. 
adreçant-se directament a la corona, alhora que la figura del virtual hereu del tron ha hagut de ser mantinguda sota la consideració de governador general. La complicació evident de les tasques administratives i la capacitat de pressió municipal anul.Ien el sistema el $1347^{26}$.

Ultra la preferència municipal per les demarcacions vicarials i batliars identificades amb les pròpies línies de puixança, estan col.lidint dos impulsos contraris. Per una banda la necessitat d'encertar tractaments administratius que superin la reducció territorial i el control municipal, encara que sigui a favor dels radis d'influència propis de les grans poblacions per damunt de les menors, segons practicaran les col.lectes dels diferents fogatges. En aquest sentit s'aniran repetint tractaments territorials intermedis, adequats a necessitats específiques, com havien aplicat ja els tribunals d'apel.lació vicarial a inicis de segle, com ara farà la tresoreria reial i com es pretendrà innovar el 1413 al braç reial ${ }^{27}$. Per altra banda, el plantejament unitari i específic del conjunt de Catalunya està essent exigit per la cohesió des d'una percepció comuna, prou evidenciada en les estratègies requerides pels diferents grups de poder, tant nobiliaris com municipals, i en el desenvolupament legislatiu i institucional.

Coherentment, l'alta representació reial sobre Catalunya mostra un caire arrelat i imprescindible que no pot ostentar la procuració o governació general, de la qual formalment n'és delegada. El tractament unitari de Catalunya és més clar que no pas la fórmula que cal adoptar, de tal manera que, mort l'infant Jaume el 1347, el monarca designa a consellers afins -l'antic governador de Barcelona Ferran de Vilafranca, Gilabert de Corbera i Jaspert de Guimerà - per a succeir-se ad regendum officium procuracionis generalis Cathalonie fins el $1351^{28}$. En aquests moments, amb Pere de Montcada, l'oficial es presenta directament com a Petrus de Montecatheno, consiliarius domini regis eiusque procurator generalis in Cathalonia ${ }^{29}$. A partir de 1358, però, la denominació torna a ser la de vicegerent, arran d'assolir l'infant Ferran la posició immediata a la corona, que manté la denominació de governador general, tal i com es consolida el 1363 en la figura del promigènit Joan. L'aparent delegació governativa sobre Catalunya es manté prou fixada com perquè aquest canvi de titularitat no l'afecti, amb Berenguer d'Abella com gerens vices gubernationis generalis in Cathalonia, títol

26 Flocel SABATÉ, El territori de la Catalunya Medieval. Percepció de l'espai i divisió territorial al llarg de l'Edat Mitjana, Fundació Salvador Vives Casajuana, Barcelona, 1997, pp. 327-329.

27 Flocel SABATE, El territori de la Catalunya medieval. Percepció de l'espai i divisió territorial al llarg de l'Edat Mitjana, Fundació Salvador Vives Casajuana, Barcelona, 1997, pp. 327-332.

28 Josefina MATEU IBARS, La delegación del poder real en Sicilia desde el reinado de Pedro III de Aragón. Sincronismos del "alter nos" en la Corona de Aragón durante los siglos XIII-XIV, "XI Congresso di Storia della Corona d'Aragona (Paermo, Trapani, Erice, 1982)», vol. 3, Accademia di Scienze, lettere e arti, Palermo, 1983, p. 353.

29 Max TURULL, Montserrat GARRABOU, Josep HERNANDO, Josep Maria LLOBET, Libre de Privilegis de Cervera (1182-1456), Fundació Noguera, Barcelona, 1991, p. 166, entre altres exemples. 
que resta estabilitzat, traduït en català com a portant veus de la general governaçió a Catalunya ${ }^{30}$.

Tot i el formulisme de la sotsdelegació, la immediatesa amb el monarca que el nomena, l'actuació efectiva sobre el conjunt territorial i la percepció popular identifiquen el portantveus com a governador de Catalunya ${ }^{31}$, denominació adoptada per Ramon Alemany de Cervelló, que ocupa el càrrec, amb algunes intermitències, des de $1374^{32}$ i que arrelarà com a gubernatoris generalis in Cathalonia ${ }^{33}$. Aquest sorgeix d'entre els consellers immediats al monarca, com els que amb facilitat mediatitzen Joan $\mathrm{I}^{34}$, tal vegada contribuint en benefici propi al malgovern, segons les veus populars ${ }^{35}$. Significativament, el governador Ramon Alemany de Cervelló procedeix d'una intensa participació en les intrigues en de la cúpula del poder ${ }^{36}$ i formarà part dels encartats en el procés contra consellers i curials del rei que seguirà a la mort del monarca ${ }^{37}$. Les circumstàncies de la darreria del segle, amb l'infant Martí absent del regne a partir de 1391 i amb un governador general, des de 1396, de no pas plena sintonia vers el monarca, accentuen el pes polític d'un governador de Catalunya que coetàniament està afermant l'activitat de la pròpia cort. A nivell personal, la prosperitat de l'alt oficial ii permet servar l'ofici malgrat canvis de reis i gaudir dels propis fills com a lloctinents, un dels quals, Guerau, el succeirà el 1404, gaudidor també de la confiança reial com a camarlenc i membre del consell reial ${ }^{38}$, de la mateixa manera que, anys abans, dos membres de l'altra branca familiar, els homònims Guillem de Cervelló, havien estat vicegerents sota Jaume II i Alfons III. A nivell polític, l'evolució és nítida: quan el 1343

30 Aquesta dualitat resta permanentment fixada: el 1393, per exemple, l'alt oficial es presenta coetàniament com Raymundus de Villanova, miles, gerensvices gubernator in Cathalonia o, en la formulació catalana, com a Ramon de Vilanova, cavaller, portantveus del Governador general en Cathalunya (ACA, Diversos, Fons Institucionals, Governació General de Catalunya, reg. 1, fol. 16r i $32 r$, entre altres).

31 Flocel SABATÉ, Governador general, "Diccionari d'Història de Catalunya», Jesús Mestre, dir., Edicions 62, Barcelona, 1992, p. 511.

32 Raymundus Alamany de Cervilione, miles consiliarius et camarlengus serenissimi domini regis et pro eodem domino Cathalonie gubernator (ACA, Diversos, Fons Institucionals, Governació General de Catalunya, reg. 1, fol. 1r).

33 AHCBa, Arxiu del Veguer, XXVI-1, llibre 1390, fol. 82v, entre altres exemples.

34 Martí de RIQUER, Torroella de Montgri en la primavera del año 1396, "Fiesta Mayor 1959», Ajuntamiento de Torroella de Montgrí, Torroella de Montgrí, 1959, sense numerar.

35 Maria Teresa FERRER, Les relacions del rei Martí l'Humà amb la ciutat de Barcelona, "VII Congreso de Historia de la Corona de Aragón (Barcelona, 1962), vol. III, Dirección General de Archivos y Bibliotecas y de Relaciones Culturales, Ayuntamientos y Diputaciones de Barcelona y Tarragona, 1962, pp. 161-162.

36 ACA, Cancelleria, reg.1726, fols. 6v-7r.

37 Marina MITJA, Procés contra els consellers, domèstics i curials de Joan l, entre ells Bernat Metge, «Boletín de la Real Academia de Buenas Letras de Barcelona», XXVII (Barcelona, 1957-1958), p. 378 .

38 Maria Teresa FERRER i MALLOL, El consell reial durant el regnat de Martí l'Humà, “XVI Congreso de Historia de la Corona d’Aragón (Jaca, 1993)», 1/2, Gobierno de Aragón, Zaragoza, 1996 pp. 181-184. 
els jurats de Girona pretenen influenciar en la designació reial del veguer, s'adrecen al procurador general ${ }^{39}$, i quan el 1401 els paers de Cervera cerquen el mateix, ho negocien amb el governador de Catalunya ${ }^{40}$.

No és estrany, doncs, que en arribar l'interregne de 1410, es pugui imposar el cessament del governador general, el candidat al tron Jaume d'Urgell ${ }^{41}$, sense que això afecti al governador de Catalunya, ans al contrari: atès el buit de poder, aquest assoleix el protagonisme màxim en el regiment del país ${ }^{42}$, tot influenciant obertament no sols en la continuïtat administrativa sinó també en la política des d'un caire clarament antiurgellista ${ }^{43}$.

Tota aquesta evolució es viu de manera diferent i particular als comtats de Rosselló i Cerdanya. Aquests havien gaudit d'un tractament unitari des del segle XII, atorgant així una entitat institucional a una dinàmica socioeconòmica comuna empentada des de Perpinyà. Coherentment, en formar part dels dominis del rei de Mallorca, entre 1276 i 1344, el monarca delega l'alta representació en un permanent lloctinent exclusiu per als comtats ${ }^{44}$ i diferent de l'existent a les illes ${ }^{45}$. L'oclusió del regne de Mallorca per les armes de Pere el Ceremoniós col.loca en mans d'aquest Rosselló i Cerdanya el mateix any en què s'aplica la reforma governativa. S'estableix així la governació dels comtats, hereva de l'anterior lloctinència, amb una efectiva i permanent actuació en l'alta representació reial sobre els comtats. Això n'assegura la continuïtat, al marge fins i tot que l'afermament del governador general imposi formalment la denominació de gerens vices gubernatoris generalis in comittatibus Rossilionis et Ceritanie ${ }^{46}$, tracte que es reiterarà posteriorment tant en l'entorn del monarca ${ }^{47}$ com del governador

39 AHCG, I.1.2.1, lligall 5, llibre 3, fol. 66v.

40 AHCC, llibre del Consell 1401, fol. 84r.

41 Cortes de Cataluña, «Cortes de los antiguos reinos de Aragón y Valencia y Principado de Cataluña», IX, Real Academia de la Historia, Madrid, 1905, pp. 67-77.

42 Com comentava Lalinde, se podía vivir sin una gobernación general (...), pero como no se podia era sin gobernadores territoriales, máximos representantes del poder (Jesús LALINDE, La gobernación general en la Corona de Aragón, Institución "Fernando el Católico», Zaragoza, 1963, pp. 182).

43 Angels MASIA DE ROS, El dissortat comte d'Urgell, Rafael Dalmau editor, Barcelona, 1960, p. 25.

44 Flocel SABATÉ, Perpinyà, capital baixmedieval dels comtats de Rosselló i Cerdanya, "800è anniversaire de la charte des libertés communales de Perpignan», Mairie de Perpignan - Université de Perpignan, Perpinyà, (en premsa).

45 Maria BARCELO, Algunes anotacions sobre la cúria de governació, "XIII Congrés d’història de la corona d'Aragó (Palma de Mallorca, 1987)", vol. II, Institut d'Estudis Baleàrics, Palma de Mallorca, 1990, pp. 8-10.

46 ACA, Cancelleria, reg. 1538, fol. 108r (ed.: Jesús LALINDE, La gobernación general en la Corona de Aragón, Institución «Fernando el Católico», Zaragoza, 1963, p. 530).

47 El 1371, per exemple, el rei s'adreça al nobili et dillecto consoliario nostro Arnaldo Dorchau, militi gerenti vices gubernatoris in comitatibus Rosilionis et Ceritanie vel eius locumtenenti (J.-B. ALART, Les stils de Villefranche-de-Conflent, Auguste Durand, libraire-éditeur, Paris, 1862, p. 42). 
genera ${ }^{48} \mathrm{i}$ es mantindrà en els nomenaments oficials ${ }^{49}$, però que en realitat resta de forma protocol.lària perquè tothom assumeix la consideració de governador dels comtats. Esdevé, d'aquesta manera, una de les institucions que evidencien i cohesionen el conjunt territorial entorn de Perpinyà, raó per la que assoleix un ple ressò popular: hom pot ubicar, el 1394, baiulie loci de Pratis infra Gubernationem Rossilione ${ }^{50}$.

La posició territorial i la funció reial apropa l'ofici al grup dels barons rossellonesos de l'entorn del monarca ${ }^{51}$, cosa que hi fa destacar personatges com els Perellós, amb dos membres de la família ocupant l'ofici en el tombant del segle XIV al XV52. En altres casos, el càrrec esdevé un esgraó en l'administració del sobirà, pujat per personatges com Ramon Alemany de Cervelló, que abans d'ocupar les governacions de València i Catalunya regí la dels comtats de Rosselló i Cerdanya entre 1361 i 1370.

\section{FUNCIONS I CORTS GOVERNATIVES}

En una administració més jeràrquica que no pas competencial com és la medieval, en la funció governativa hi pesa sobretot l'alta posició d'ostentar la més elevada delegació règia. El procurador o el governador general assumeixen totes les capacitats del monarca, ja sigui per delegació directa d'ell o per pròpia iniciativa, afectant tots els afers polítics, la intervenció en feus reials, la comunicació amb els oficials mitjans, la conducció d'hosts o l'avocació judicial. Precisament, i a partir d'una concepció del poder superior altament judicial ${ }^{53}$, l'exercici de la justícia ha esdevingut des dels primers moments un distintiu de la delegació immediata del sobirà ${ }^{54}$, a voltes assumint apel.lacions, especialment en casos de febles i menors, que poden ser perllongades amb un posterior recurs a la cort reial ${ }^{55}$.

48 Gerens vices nostras in comitatibus Rossilionis et Ceritanie vel eius locumtenens diu l'infant Joan el 1368 (Ferran VALLS i TABERNER, Privilegis i ordinacions de la vall de Ribes, Universitat de Màlaga, Zaragoza, 1992, p. 569).

49 Ramon Sagarriga el 1387, per exemple, rep l'ofici gerentem vices gubernatoris generalis in dictis comitatibus Rossilione et Ceritanie (ACA, Cancelleria, 1912, fol. 9v).

50 ACA, Cancelleria, reg. 2043, fol. 74r.

51 Ramon D'ABADAL, Pere el Ceremoniós $i$ els inicis de la decadència politica de Catalunya, Edicions 62, Barcelona, 1987, p. 86.

52 Es tracta de Ramon de Perellós, el baró de Jóc mort el 1384, i del seu renebot homònim. L'homonímia de la família ha portat a confondre-hi un altre Ramon de Perellós, pare de l'anterior, nebot del primer i també molt proper a la corona, que pròpiament ocupà la capitania del Rosselló des de 1389. Aquestes confusions ja foren advertides a: Maria Teresa FERRER, Noves dades per a la biografia de Ramon de Perellós, autor del "viatge al Purgatori de Sant Patrici", «Miscel.lània en honor del Doctor Casimir Martí», Fundació Salvador Vives Casajuana, Barcelona, 1994, pp. 221-222.

53 Jesús LALINDE, El ordenamiento interno de la Corona de Aragón en la época de Jaime I, «X Congreso de Historia de la Corona de Aragón (Zaragoza, 1979)», Institución «Fernando el Católico», Zaragoza, 1980, vol. I, p. 186.

54 Lope PASCUAL MARTINEZ, Los oficios en la Corte de Pedro III de Aragón (1276-1285), «XI Congresso di Storia della Corona d'Aragona (Palermo-Trapani-Erici, 1982)", vol. IV, Academia di Scienze, lettere e arti, Palermo, 1984, pp. 46-47.

55 AHCV, pergamí 112. 
Bé que la concessió de privilegis o la cessió de jurisdicció es cenyeix a l'actuació del procurador o el governador general per la seva immediatesa a la corona ${ }^{56}$, pel que fa a la gestió, el vicegerent i el portantveus assumeixen les mateixes competències, desenvolupades segons l'evolució dels respectius oficis. La vicegerència sota un procurador general menor d'edat d'inicis de segle XIV i la governació de Catalunya rera un governador general força protocol.loritzat de finals de la mateixa centúria afermen una pròpia actuació de línia directa amb el monarca, que es compagina amb l'actuació de procuradors generals com els infants Alfons i Pere que es preparen per a rebre el tron o de governadors generals com l'infant Joan en les mateixes circumstàncies. Només en determinats casos concrets ambdós es combinen, com en remissions generals atorgades pel governador general a partir de la inquisició efectada pel portantveus ${ }^{57}$.

En representar el sobirà, el titular governatiu es col.loca jeràrquicament damunt dels oficials districtuals, els veguers. D'aquí deriva una atenció sobre els representants reials ${ }^{58}$, incloent intervencions en conflictes competencials, segons es viu a Copons el $1391^{59}$, o limitacions en excessos d'actuació, com en recriminar, el 1446, el guiatge ofert a Sant Feliu de Guíxols pel procurador fiscal de la batllia, com lo dit procurador fiscal sie official qui no haia exercici de alguna juridicción ${ }^{\circ}$. Tanmateix, una relació directa, que comporti la capacitat de nomenament i de control usual de veguers $i$ sotsveguers, sols la coneixen el procurador per a Catalunya de la darreria del segle $\mathrm{XIII}{ }^{61} \mathrm{i}$ els supraveguers ${ }^{62}$, tot perllongant-se de forma ocasional sota Jaume $\mathrm{II}^{63}$. Superat aquest període, la designació com el tracte usual i directe es vincula amb la corona, per la mateixa preeminència del sobirà i per la constatació de fisures en uns oficials que, fins i tot quan són designats pel delegat reial, es descriuen, cadascun d'ells segons recorda el mateix monarca, com a vicarius regis ${ }^{64}$.

El suport al monarca justifica col.laboracions en matèria de regalies. Sota aquesta invocació l'actuació governativa es reitera en casos de pirateria o de troballes al mar ${ }^{65}$ $i$, bé que en les defenses de vidua, pubil o altre miserable el monarca sol preferir la intervenció amb la pròpia cort, el governador pot entrar en suport del monarca, com es repeteix a la segona meitat del segle $X^{66}$. En un sentit semblant, l'alt oficial s'ofereix, en nom reial, per a pacificar enfrontaments, fins i tot aliens a la jurisdicció reial ${ }^{67}$, atenent

56 AHCBE, Universitat de Palamós, pergamí 16; AHCG XV.4, lligall 1, llibre 2, sense numerar, com exemples d'ambdós suposits.

57 AHCT, pergamins, caixa 10, pergamí 1376.

58 ACA, Cancelleria, regs. 240, fol. 138r; 507, fol. 124r-v; 954, fol. 113r.

59 ACA. Diversos. Fons institucionals. Governació General de Catalunya, reg. 1, fol. $4 \mathrm{v}$.

60 ACA, Diversos. Fons institucionals. Governació General de Catalunya, reg. 18, fol. 52r.

61 AHCM, Fons municipal, manuale concilii 1292-1311, sense numerar.

62 ACA, Cancelleria, reg. 231, fol. 66r.

63 ACA, Cancelleria, Varia, reg. 275, sense numerar.

64 ACA, Cancelleria, reg. 231 , fol. 66 r.

65 AHCTE, Governador, 21, fols. 1r-29v.

66 ACA, Diversos. Fons Institucionals. Governació General de Catalunya, reg. 18, fols. 45v-46r.

$67 \mathrm{ACV}$, calaix 9 pergamí sense numerar (1304). 
els conflictes de jurisdicció, tant entorn de competències territorials com d'adscripcions personals ${ }^{68}$.

Les fortes divisions en bàndols i les tibantors de veïnatge s'accentuen amb el segle XIV i faciliten intervencions governatives paradigmàtiques - cas de Cervera el 1388efectuant detencions, com a Vic el $1385^{69} \mathrm{o}$, molt més freqüentment, imposant remissions, com a Anglesola el $1379^{70}$. La gravetat de les situacions facilita una creixent presència del governador, com en les actuacions derivades de l'assalt als calls el 1391'1, tant per a procedir-hi directament ${ }^{72} \mathrm{com}$ per a intercedir davant els inquisitori hereticorum ${ }^{73}$. Amb aquestes activitats, garantir la pau, l'ordre i la justícia esdevenen divises teòriques de Governació en tant que encarregada d'executar i governar l'àmbit considerat propi del sobirà.

La combinació de les preocupacions per les prerrogatives reials i per les vies de la pròpia penetració en els diferents àmbits de poder justifica les actuacions sobre diversos governs municipals, sobretot a la sortida del segle XIV arran de convocatòries d'host sense autorització dels oficials reials ${ }^{74} \mathrm{o}$ al.legant enfrontaments en els procediments municipals ${ }^{75}$. En aquests moments, l'elevat pes polític assolit pel governador augmenta les intervencions en afers diversos, com succeeix en 1399 en pretendre arbitrar a Berga en les diferències entre el lloctinent de procurador fiscal $\mathrm{i}$ els teixidors de la vila ${ }^{76}$.

En realitat, la cort del governador al darrer quart del segle XIV es consolida com un dels àmbits més sol.licitats de l'administració. Rep i tracta apel.lacions, en el sentit més ample, que qüestionen sentències, empares, deutes, empresonaments, exigències de marques per fadiga de dret i qualsevol actuació dels diferents oficials reials. Les presenten els diferents particulars afectats i també altres membres de l'administració reial, especialment de la tresoreria ${ }^{77}$ o també procuradors i advocats fiscals territorials, aquests sovint per diferències recaptatòries amb els municipis ${ }^{78}$. Això comporta una intensa intervenció governativa en tots els territoris de jurisdicció reial de Catalunya, amb un notori intercanvi epistolar, a voltes amb poders baronials i municipals, però sobretot amb els diferents oficials territorials $i$ jurisdiccionals reials, des de batlles $i$ veguers amb els membres de la seves corts - jutges, escrivans, col.lectors de

68 AHMV, Llibre de privilegis XXV, pergamí 434.

69 AHMV, llibre de Privilegis II, pergamí 34.

70 ACA, Cancelleria, «Papeles por incorporar», 1379, sense numerar.

71 Jaume RIERA i SANS, Els avalots del 1391 a Girona, Jornades d'Història dels jueus a Catalunya (Girona, 1987), Ajuntament de Girona, Girona, 1990, p. 135.

72 ACA, Diversos. Fons Institucionals. Governació General de Catalunya, reg. 1, fol. 3v.

73 ACA, Diversos. Fons Institucionals. Governació General de Catalunya, reg. 1, fol. $5 \mathrm{v}$.

74 AHMV, Llibre de Privilegis VI, pergamí 112.

75 AHMV, Llibre de Privilegis IV, pergamí 68.

76 ACA, Cancelleria, reg. 2029, fol. 166r.

77 ACA, Diversos, Fons Institucionals, Governació General de Catalunya, reg. 1, fol. 4r, per exemple.

78 ACA, Diversos, Fons Institucionals, Governació General de Catalunya, Ilbre 1, fol. 16v, per exemple. 
terces...- als consols de mar. Conseqüentment, se'n derivaran retocs o modificacions completes de decisions vicarials o batliars, tant en sentències com en aplicacions d'empares ${ }^{79}$.

La consolidació d'aquesta cort hi atrau molts ciutadans, sobretot de Barcelona, per a registrar-hi obligacions. Es el mateix procediment coetàniament seguit en les altres corts ordinàries, i en el volum, contingut i forma aprofita i evidencia les circumstàcnies de la darreria del segle XIV i la quinzena centúria. El nombre d'obligacions econòmiques és proporcionalment més reduït que no pas les coetàniament usuals a les corts batliars i vicarials. En coincidència, amb la funció d'ordre públic invocada com a pròpia de la governació reial, els manaments o obligacions més freqüents s'estableixen per a garantir paus privades, ja sigui per aturar animadversions registrades com individuals ${ }^{80} \mathrm{O}$ de bàndols, en les que aniran compareixent i firmant la còrrua dels respectius partidaris ${ }^{81}$. Als acords de pax finalis ${ }^{82}$, segueixen, per volum de registres efectuats, els de treves $i$, tot seguit, les obligacions o manaments - securitas-, on s'hi inclouen els casos d'adulteri i persecució sexual ${ }^{33}$.

79 AHCBa, Arxiu del Veguer, XXVI-1, llibre 1390, fol. $118 \mathrm{r}$.

80 Per exemple: Die sabbati XXVII mensis iulii, anno a nativitate Domini M CCCC XXXX Tercio. De part del molt honorable governador de Cathalunya de consell del honorable micer $P$. Ledó, regent l'assessoria, ffets manament a na Eulalia, filla d'en Jordi Comes, saig de la cort del batle de Barchelona, que d'aqui avant no digue en Jacme Bonet, notari, nagunas peraules injurioses en nenguna part de Barchelona ni en altres parts, e açò sots pena d'ésser mesa en presó e ésser stobada per los lochs acostumats de la dita ciutat, lo qual manament se fa a instància del dit Jacme Bonet. Dicta die fuit factum ipsum preceptum personaliter dicte Eulalie dimittendo sibi in scriptis per lohannem Huguet, portarium (ACA, Diversos. Fons Institucionals. Governació General de Catalunya, reg. 14, fol. 1r).

81 ACA, Diversos. Fons Institucionals. Governació General de Catalunya, reg. 14, fols. 25r-27v.

82 Die iovis VIIII mensis septembris anno predicto a nativitate Domini $M^{\circ}$ CCCC $^{\circ} X X X X$ V‥ Pax finalis facta et firmata inter lohannem de Nardat, textorem pannio lini ex una et lohannem de Lombier sutorem habitatores Barchinone partibus ex altera, promiserunt alter alteri non facere aliquod damnum iniuriam vel offensa et si contrarium feceriunt volunt incidi in penam centum librarum iure et etiam prestiterunt homagium ore et manibus lohanni Vendrell, algutzirio gubernationis, renunciando et etiam obligando persona et omnia bona sua et etc. Testes firme lohannis de Nardat, Bartholomeus Riber, pellicerius et Ffranciscus Cerda, scriptor cives Barchinone. Testes Marchus Yvanyes, perator et Bartholomeus Alçamora, sutor cives Barchinone (ACA, Diversos. Fons Institucionals. Governació General de Catalunya, reg. 17, fol. 1v).

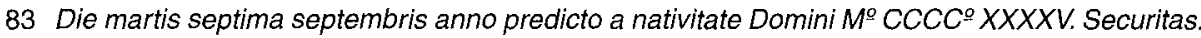
Ffranciscus de Deo, sartor civis Barchinone, virtute iuramenti et homagii inferius designati promisit multum honore domino gubernatori non contribuere carnaliter cum lohanna uxore lohannis Seguer, alter lo Prapa, calsaterii olim civis Barchinone, nec erit cum ipsa in aliquibus locis circunclausis nec cohopertis nec suspectis, et si contrarium fecerit voluit incidi in pena exili ab hac civitate in eternum iure et etiam prestitit homagium ore et manibus lohanni Vendrell algutzirio gubernationis Cathalonie generalis obligans pro hiis personam et omnia bona sua, etc. Testes Petrus Gener Fusterius, Michael Codo, payerius et lohannes de Gran, sagio cives Barchinone. // Ffranciscus de Deo, sartor civis Barchinone, gratis etiam promisit multum honore domino gubernatori non facere aliquod dampnum, iniuriam vel offensam in persona et bonis lohanne uxoris lohannis Seguer, alter lo Prapa, calçoterii olim civis Barchinone, nec curabit de ea ullomodo, et si contrarium fecerit voluit incidi in penam 
Les execucions que s'hauran d'aplicar a partir d'aquests fets comporten els registres d'acceptació de penes pecuniàries — promisit et solvere-, les seves execucions, sota pena doble en cas d'incompliment ${ }^{84}$, empares... Alhora, l'elevada intervenció governativa en els afers d'ordre públic imposa una reiterada actuació en atorgar guiatges i llicències, que solen contradir els ordinaris.

El caire imprescindible del vicegerent 0 del portantveus justifica que les seves absències siguin cobertes per un lloctinent ${ }^{85}$, figura limitada per les corts de Montsó de $1363 \mathrm{i}$ de Tortosa de $1365^{86}$, però que coetàniament assoleix un tracte propi i específic ${ }^{87}$, arrelat en les actuacions del tombant del segle XIV al XV ${ }^{88}$. Sol procedir del mateix entorn reial, on pot participar del consell, com, a la darreria del segle XIV, succceix amb Guillemus de Reiadello, miles, consiliarius et algutzirius serenissimi domini regis et locumtenente gubernatoris Cathalonie generalis ${ }^{89}$.

Per a materialitzar les diferents funcions el governador disposa d'una cort completa, amb assessor, procurador fiscal i escrivania. A més, les obligades garanties judicials imposen comptar amb l'advocat fiscal dels pobres, un jurista que atorga l'assistència jurídica als mancats de recursos.

L'assessor sol ser un batxiller en lleis d'origen urbà, fins i tot doctor, segons es reitera en el segle $\mathrm{XV}$, ben proper a la cort reial90 i molt sovint de Barcelona. Com a totes les corts jurisdiccionals, és imprescindibles a costat del titular de governació en els judicis, en el constant assessorament jurídic $i$ en decretar detencions, citacions, empares... Des dels primers moments el monarca ha estat atent a aquest ofici, raó per la que indica al vicegerent, com fa el 1333, qui ha d'actuar tanquam vestri assessore ${ }^{91}$, per acabar designant-lo directament. La necessitat que estigui dotat de gran probitat, sufficiència, sciència e de bona fama e consciencia justifica que, a partir de les corts de 1419, el rei hagi d'escollir l'assessor d'entre la terna presentada pel canceller o el

quinquaginta librarum iure et etiam prestitit homagium ore et manibus venerabili lohanni Vendrell algutzirio gubernationis Cathalonie generalis obligans per hiis personam et omnia bona et etc. Testes Petrus Janer, fusterius, Michael Codo, payerius, et lohannis de Gran, sagio civis Barchinone (ACA, Diversos. Fons Institucionals. Governació General de Catalunya, reg. 17, fol. 1r).

84 cum sit debitum fiscale et penam dupli incurre prout in dicta obligacione recepta in curia nostra (ACA. Diversos. Fons institucionals. Governació General de Catalunya, reg. 18, fol. 51r).

85 ACA, Cancelleria, reg. 525, fol. 293v; AHCBa, Fons municipal, B-I, llibre 21, fol. 44r.

86 Que.l portant veus de procurador, o governador general, e qualsevol altre qui regesca lo dit offici, per qualque nom sie appellat, no puxa loctinent constituir, e per altre fer regir, ells stants dins io Principat de Cathalunya (Constitucions y altres drets de Cathalunya, llibre I, títol XXXXI, cap. V; Joan Pau Martí y Joseph Llopis, estampers, Barcelona, 1704, facsímil: Departament de Justícia de la Generalitat de Catalunya, 1995, p. 103).

87 ADPO 1B-364, fol. 118r.

88 AHCO, pergamins, sèrie A, 224; ACA, Cancelleria, 2029, fol. 166r, entre molts altres.

89 ACA, Diversos. Fons Institucionals. Governació General de Catalunya, reg. 1, fol. 2 r.

90 Ramon Vinader, bon assistent de Jaume II, és l'exemple més nítid (Flocel SABATÉ, Les castlanies i la comissió reial de 1328, "Estudios sobre renta, fiscalidad y finanzas en la Cataluña bajomedieval», Manuel Sánchez, comp., CSIC, Barcelona, 1993, pp. 177-178).

91 ACA, Cancelleria, reg. 528, fol. 246r. 
vicecanceller, alhora que es vetlla per la seva integritat en impedir que rebi diners de les parts litigants ${ }^{92}$. Clar que, com en altres casos de l'administració, les garanties legals poden esquivar-se si en comptes d'un assessor es deixa l'ofici vacant i s'anomena, per a cobrir el buit amb plenitud de facultats, un regent de l'assessoria ${ }^{93}$.

El procurador fiscal - procurator fiscalis curie dicti vices gerentis gubernatoris Cathalonie - també com a totes les corts coetànies, assoleix un paper destacat en les causes judicials i en les indagacions que se'n derivin, alhora que ha de col.laborar en la cura de les rendes i interessos reials, atent als scandala et delicta regaliis domini regis lesive ${ }^{94}$, cosa que l'apropa, en determinats moments, a la batllia general. L'estabilitat de l'ofici permet a Antoni d'Agramuntell ${ }^{95}$, a la darreria de la catozena centúria, lligar-lo a la pròpia família, tal com a mitjan segle XV exerceix Andreu d'Agramuntell ${ }^{96}$.

L'escrivania - scribaniam et sigillum officii vices gerentis procuratoris in Cathalonie $^{97}$ - és oferta a un notari que l'adquireix de la corona, com les altres escrivanies reials ${ }^{98} \mathrm{i}$ que la farà funcionar amb els seus auxiliars, que s'encarregaran de registrar totes les activitats i d'oferir-ne trasllat als sol.licitants sota les taxes ordinàries, a més de vetllar per la cura del segell i atendre l'arxivament de la documentació. El creixement de l'activitat, sobretot a la darreria del segle XIV, imposa registres especialitzats, amb llibres específics per a lletres comunes, cúria, fermes $\mathrm{i}$ obligacions, remissions i guiatges, processos, sentències...99. A partir d'aquestes activitats, els mateixos escrivans van especialitzant-se en les diferents activitats $i$ anotacions.

A més, la recaptació dels ingressos de la cort, sobretot arran de la imposició de penes pecuniàries, porta a especialitzar, sobretot en el segle $\mathrm{XV}$, el receptor iurium et emolumentorum Gubernationis Cathalonie.

La cort disposa d'un algutzir, el nomenament del qual ha estat des dels primers moments força mediatitzat pel monarca, qui el tria en àmbits propers, a voltes, com diu el 1332, sota el consell de quorumdam familiarium nostrorum ${ }^{100}$. Es un càrrec significatiu, en tant que esdevé el rostre superior de la governació. Davant seu es garanteixen els manaments, obligacions i pactes pels que la població acut a la cort,

92 Cortes de Cataluña, "Cortes de los antiguos reinos de Aragón, Valencia y Principado de Cataluña», XII, Real Academia de la Historia, Madrid, 1908, pp. 331-332.

93 ACA, Diversos. Fons d'institucions. Governació General de Catalunya, reg. 14, fol. 37r.

94 ACA, Diversos, Fons Institucionals. Governació General de Catalunya, reg. 14, fol. 8r.

95 AHCBa, Arxiu del Veguer, XXVI-1, llibre 1395, fol. 55v.

96 ACA, Diversos, Fons Institucionals. Governació General de Catalunya, reg. 14, fol. 13v..

97 ACA, Cancelleria, reg. 505, fol. $173 \mathrm{v}$.

98 A partir d'aquesta pràctica, l'escrivania del governador de Catalunya va anar a raure a mans privades, d'on fou recuperada per l'administració pública vers 1901 (Rafael CONDE, Diversos, «Guia histórica y descriptiva del Archivo de la Corona de Aragón", Federico Udina, dir., Ministerio de Cultura, Madrid, 1986, p. 391).

99 ACA, Diversos, Fons Institucionals. Governació General de Catalunya, regs. 1-29; 77-78.

100 ACA, Cancelleria, reg. 507, fol. 122r. 
alhora que ha d'auxiliar el vicegerent o portantveus en els afers territorials, moltes vegades desplaçant-se a tractar afers concrets o, en casos concrets, per a traslladar detinguts. Tota aquesta activitat aferma la posició de l'algutzir i la presència, en les seves absències, d'un lloctinent. Precisament, és aquest qui cada cop més realitza els desplaçaments pel territori ${ }^{101}$. De tota manera, l'evolució, pròpia de tots els algutzirs, preocupa el poder municipal i arriba a les corts de 1419 en voler limitar que el algutzirs reials i del governador general per si no puixen tenir Cort ne juy ${ }^{102}$.

També es compte amb un porter, que en el període de les governacions territorials (1343-1347) desenvolupa les funcions de l'algutzir. De fet, a de la sortida del segle XIV i encara més en el XV garanteix asseguraments a costat de l'algutzir, com en les paus finals en què les parts enfrontades prestiterunt iurium et homagium ore et manibus comendatum in posse lacobi de Viçles, algutzirii, et Petri Rossell, porterii curie gubernationis Cathalonie ${ }^{103}$. De manera més específica, al llarg de tot el període, sol ser qui es desplaça per als trasllat de detinguts sota ordre governativa ${ }^{104} \mathrm{i}$ qui desenvolupa la important funció de distribuir l'elevat volum de citacions, manaments i altres requeriments de la cort ${ }^{105}$.

En aquestes tasques la cort governativa és auxiliada, de manera fixada des de l'antepenúltima dècada del segle XIV, per porters de la cort reial, pagats per la governativa a raó de cada acte fet en servei d'aquesta. Igualment, segons les actuacions concretes, hi caldran reforços de nuncis, missatgers i macips. Sense ser usual, però una mica més freqüentment, les tasques de requeriments i lliurament de citacions o d'execucions de detencions solen demanar l'ajut de saigs de les corts vicarials o batliars amb jurisdicció, sovint esquerpes en témer-hi ingerències excessives.

També en els procediments judicials l'actuació governativa pot desenvolupar-se mitjançant la delegació del cas en juristes locals. Es una pràctica que, a l'igual que a la cort reial, és més usual a inicis de segle, bé que es perllonga en determinats casos d'apel.lació d'ordinaris ${ }^{106} \mathrm{i}$ a la que en part respon el reconeixement de Joan l emès el $1395^{107}$. Semblantment i malgrat les malfiances locals de la quatorzena centúria, en el segle XVel governador delega comissaris per a tractar afers concrets, com a Lleid on

101 ACA, Diversos, Fons Institucionals, Governació General de Catalunya, Ilbre 1, fol. 5 r.

102 Cortes de Cataluña, "Cortes de los antiguos reinos de Aragón, Valencia y Principado de Cataluña», XII, Real Academia de la Historia, Madrid, 1908, p. 310.

103 ACA, Diversos, Fons Institucionals. Governació General de Catalunya, reg. 14, fols. 7v-8r.

104 ACA, Diversos, Fons Institucionals. Governació General de Catalunya, regs. 14, fol. 8r; 29 , fol. $13 \mathrm{v}$, entre altres.

105 Petrus Rossell predictus (porter) reculit se mandato dicti domini gubernatoris mandasse lohanni Vidal, barberio Gerunde quatenus infra tres dies solveret Arnaldo Forsos, flassaderio Gerunde, rectam peccuniam quantitatem in qua sibi tenetur (ACA, Diversos. Fons Institucions. Governació General de Catalunya, reg. 14, fol. 145r).

106 AHCV, pergamí 112.

107 Jesús LALINDE, La gobernación general en la Corona de Aragón, Institución «Fernando el Católico», Zaragoza, 1963, p. 370. 
l'actuació es culmina el 1486, en paraules del governador, amb la sententia lata per Bernardum Giro, iurisperitum dicte civitatis llerde, comissarium per nos assignatum ${ }^{108}$.

El procediment judicial en l'àmbit governatiu és idèntic a l'efectuat en les altres corts, amb l'assessor a costat del governador, el procurador fiscal i l'escrivà, representant l'enfrontament entre la part agent, que si cal serà el procurador fiscal ${ }^{109}$, i la defenent mitjançant l'exposició de capítols i, si es veu adient, l'exposició de testimonis a través de la presentació de cèdules al llarg de les diferents sessions ${ }^{110}$. L'estabilitat de la cort es contradiu amb la seva definició com a simple auxiliar de l'oficial governatiu. Per això, en els casos seguits en judici no poques vegades una part reclama la il.legalitat de les actuacions per haver-se produït quan l'alt delegat reial non est presens in dicta Civitate $^{111}$, plantejament que aboca a tensions respecte a la capacitat respectiva d'actuació.

La nombrosa activitat de la cort del governador imposa, en els requeriments i citacions, un tracte amb les altres corts reials, en les que es solen registrar les demandes, per a evitar problemes amb els àmbits locals ${ }^{112}$. Per ordre del governador s'exigirà al corresponent escrivà la tramesa de trasllats de processos ${ }^{113}$, a indicació de l'assessor ${ }^{114}$, o s'encarregarà la materialització d'empares, citacions o manaments específics, fins $i$ tot obligacions d'acceptar determinades defenses en casos que afecten l'entorn reial ${ }^{15}$.

108 ACA, Diversos. Fons institucionals. Governació General de Catalunya, reg. 18, fol. 52v.

109 AHMV, Llibre de Privilegis IV, pergamí 68.

110 AHMV, Llibre de Privilegis VI, pergamí 112.

111 AHCT, Fons municipal, sèrie processos, secció administració de justícia, 1342, fol. 31v.

112 Per exemple, el 1395, a la cort vicarial de Barcelona es recull, entre altres, que Petrus Ihoannis, portarius domini regis, dixe quod ipse de mandato nobilis gubernatoris Cathalonie et ad instantiam procuratoris fischalis dicte gubernationis, fecit preceptum discreto Petro de Ortis, notarium Barchinone, in scriptis sub forma sequenti: De part del Governador manats an Pere d'Orts, notari de Barchelona, que façe translat de l'inventari que n'Anthoni Font féu dels béns que li romangueren de sa mare, 10 qual translat lo procurador fischal del governador ha mester per fundar ça intenció, e que sia donat an Anthoni d'Agramuntell, procurador fischal de la governació, o an Thomàs Sanabre en loch seu (AHCBa, Arxiu del Veguer, XXVI-1, llibre 1395, fol. 55v).

113 Com s'esdevé a la cort del veguer de Barcelona el 22 de setembre de 1395: Petris lohannis portarius domini regis dixe quod ipse ex parte dicti domini et ex mandato sibi facto per nobilem gubernatorem Cathalonie fecit preceptum discreto Anthonio ça Plana, notaril et scribe curie vicarie Barchinone, et penam $D$ florenos imposuit quod instrumenti facit translatum de processu originali inquisitionis facte contra Bernardo Vigara (AHCBa, Arxiu del Veguer, XXVI-1, llibre 1395, fol. 153r).

114 AHCBa, Arxiu del Veguer, XXVI-1, llibre 1390, fols. 81r i 118 r.

115 Petrus lohannis portarius domini regis dixe quod ipse ex parte nobilis viri Raymundi Alamanni de Cervilione, gubernatoris generalis in Cathalonia et de consilio venerabilis Bernardus de Olivaria, in legibus licenciati assessoris dicti nobilis gubernatoris, fecit preceptum, necnon penam centum morabatinorum imposuit venerabile, Bernardus de Villagayano legum doctori civique Barchinone prestet patrocinium sive advocationem venerabili Petro Medici, de thesauraria domine regine in causa seu questione que dicitur inter ipsum Petrum Medici ex una parte et dominam Constanciam uxorem discreti Ffrancisci de Relat, notarium Barchinone, quod preceptum dixe se fecisse ad instanciam dicti venerabili Petri Medici (AHCBa, Arxiu del Veguer, XXVI-1, llibre 1390, fol. 82v). 
La preocupació super negociis et iuribus feudorum Cathalonie ${ }^{116}$, objecte de reiterades procuracions especials en connexió amb la batllia general ${ }^{117}$, troba, en la seva concreció arreu del territori, una combinació amb les governacions endegades entre 1344 i 1347 . En cadascuna d'elles es situa un procurador reyal e procurador dels feus los quals lo senyor rey ha en la governació, que desenvolupa officium procuracionis regie gubernacionis, atent a l'evolució dels drets i rendes del monar$\mathrm{ca}^{118}$, a més de gestionar econòmicament la governació ${ }^{119}$. Aquest resseguirà les diferents vegueries encabides, en les quals s'avançarà vers una representació estable, amb certa similitud amb la procuració reial que ja funcionava als comtats de Rosselló i Cerdanya, mitjançant un lloctinent o substitut de procurador reial a cada demarcació ${ }^{120}$. L'activitat generada exigeix una escrivania pròpia per a cada procuració, a més de l'assistència d'un verguer o porter — porter de verga de la Procuració-.

En els comtats de Rosselló i Cerdanya, el protagonisme del governador concorda amb una elevada activitat, més nombrosa, menys discutida i més ordinària que el seu homòleg al Principat. Assumeix la representació del monarca, intervé en tots els afers de govern, des dels controls de la gestió ${ }^{121}$ dels oficials mitjans i inferiors ${ }^{122}$ a l'atenció a l'abastament de queviures ${ }^{123}$, el desenvolupament dels diferents indrets ${ }^{124} \mathrm{i}$ el suport a l'atenció per les rendes reials ${ }^{125}$ mitjançant garantir les actuacions de procuració reial -com en l'assumpció de les penes intimidatòries ${ }^{126}$, l'aplicació d'empares ${ }^{127}$ o la cura dels seus oficials ${ }^{128}$ - o exigir el correcte ús dels béns de titularitat reial ${ }^{129}$, a més d'assumir, des de la representació jurisdiccional superior, els tractes diplomàtics amb

116 ACA, Cancelleria, Procés en foli 9/2, fol. 2r; Batllia General, 37, fol. $1 \mathrm{r}$.

117 Flocel SABATÉ, Les castlanies i la comissió reial de 1328, «Estudios sobre renta, fiscalidad y finanzas en la Catalunya bajomedieval», Manuel Sánchez, comp., CSIC, Barcelona, 1993, pp. 226241.

118 Prim BERTRAN, El «Liber feudorum viccariae Pallariensis», «llerda», XXXVIII (Lleida, 1977), p. 88 .

119 Prim BERTRAN, La procuració reial de Lleida a mitjans del segle XIV, Estudio General de Lérida, Lleida, 1981, pp. 3-9.

120 ACA, Cancelleria, reg. 955, fol. 26v.

121 ACP AA5, fol. 60r-v.

122 Davant seu els veguer, scrivà, collidor de clams, reclams e de terces e encara lurs lochtinents e substituts s'han de comprometre a usar bé e leyalment, tota frau cessant, en fer les composicions pertanyents al dit offici (ADPO 1B-350, fol. 10v).

123 ACA, Reial Patrimoni, Mestre Racional, 1522, fol. 309v.

124 ADPO 1B-254, fol. 23v.

125 ADPO 1B-346, fols. 45r-52v.

126 ADPO 1B-145, fol. 30r-v; ACA, Cancelleria, regs. 1970, fol. 1r; 2006, fol. 5 r.

127 ADPO $1 \mathrm{~B}-163$, fol. 50r.

128 ACA, Cancelleria, reg. 2217, fol. 11r.

129 Per això s'encararà, per exemple, als cònsols de Tuïr en relació a l'ús de l'important rec (ADPO 1B-163, fol. 35r, 83r). 
un veïnatge francès de reiterat contacte en les diferents activitats socioeconòmiques ${ }^{130}$. Esdevé el màxim responsable en l'atenció a les defenses ${ }^{131}$, la prevenció davant atacs foranis ${ }^{132}$, la coordinació en la vigilància i la comunicació defensiva ${ }^{133}$ o la imposició de la recollida de la població en els recintes fortificats ${ }^{134}$. La situació fronterera dels comtats de Rosselló i Cerdanya accentua la funció militar del seu governador al front de les hosts ${ }^{135}$, amb actuacions de fort ressò com les anades de 1370 al comtat d'Empúries ${ }^{136}$ o la de 1397 a la Seu contra el comte de Foix ${ }^{137}$. Ja el 1390 el governador general és reforçat com a capità general ${ }^{138}$, posició desitjada el 1410 per a evitar divergències ${ }^{139}$ i reiterada al llarg del segle $X V^{140}$, per bé que s'imposa una separació que permet accentuar la militarització de l'un i el vessant més politicoadministratiu de l'altre, tal com es viu en entrar als segles moderns, amb topades mútues incloses ${ }^{141}$. Sols resta fora de l'esguard d'aquest governador septentrional el patrimoni reial, que pertany a la procuració reial dels comtats i esdevé causa d'algunes interferències que poden fer modificar inicials plantejaments governatius ${ }^{142}$.

L'elevada activitat justifica el lloctinent del governador ${ }^{143}$, funció reiteradament en mans perpinyaneses, tot reflectint el pes de la capital dels comtats ${ }^{144}$. Avança vers un caire permanent que a mitjan segle $X V^{145}$ és de designació reial' ${ }^{146}$. De fet, ja anteriorment, quan sota el regne de Mallorca l'ofici l'exercia el lloctinent reial, aquest

130 El 30 de juliol de 1358 el governador, acompanyat pel veguer de Rosselló i un saig, anaren al loch d'Estagel, que ageren vistes ab lo senescal de Carcassona e ab altres officials del Rey de Ffranssa (ACA, Reial Patrimoni, Mestre Racional 1522, fol. 338r).

131 ACA, Reial Patrimoni, Mestre Racional 1501, fol. 88v.

132 El 1395 el governador envia per mà de I traginer de Puigcerdà de continent lo dit veguer $e$ mana ses letres e tramès per Conflent ffassen ab les dites letres manament a la gent de gardassen bé lur fforsses de nits e de dies, e sapiats que ab aquestes pluges són enbausats e diverses lochs de Conflent part de les forsses (ADPO 1B-163, fol. 31r).

133 ADPO 1B-257, fol. 152r.

134 ACA, Reial Patrimoni, Mestre Racional 1521, fol. 32r.

135 ACA, Reial Patrimoni, Mestre Racional 1528, fols. 270v-271r.

136 ACP AA5, fol. 38r.

137 AHCO, Fons notarial, Secció Besalú, reg. 285, sense numerar.

138 ACA, Cancelleria, reg. 1914, fols. $60 \mathrm{v}, 133 \mathrm{v}$.

139 accedendo ad comitatum Rossilionis et Ceritanie pro concordando et uniendo Gubernatorem et Capitaneum dictorum comitatum et villam Perpiniani super nonnullis controversiis inter eos exortis prout fuerat propositum (Cortes de Cataluña, "Cortes de los antiguos reinos de Aragón y Valencia y Principado de Cataluña", IX, Real Academia de la Historia, Madrid, 1905, p. 33).

140 ACA, Cancelleria, reg. 3296, fol. 11v-12r; 3357, fol. 56r.

141 Angel CASALS, Estructura defensiva de Caatalunya a la primera meitat del segle XVI: els comtats de Rosselló i Cerdanya, "XVI Congreso de Historia de la Corona d'Aragón (Jaca, 1993)", tomo I, vol. 2, Gobierno de Aragón, Zaragoza, 1996 pp. 89-92.

142. ADPO 1B-225, fol. 82r.

143 ADPO 1B-346, fol. 31r.

144 ADPO 1B-346, fol. 71v.

145 ADPO 1B-254, fol. 23v.

146 ACA, Cancelleria, regs. 3296 , fol. $11 \mathrm{v}-12 \mathrm{r}$; 3357 , fol. $56 \mathrm{r}$. 
podia designar, per a casos d'absència, un representant propi, el portantveus del lloctinent.

El governador dels comtats de Rosselló i Cerdanya, per la seva posició en l'organigrama reial, rep el jurament inicial d'alguns batlles, com els de Perpinyà, Argelers, Morellàs o ocasionalment el Voló ${ }^{147}$, funció que en altres contrades és en mans de veguers, batlles o jutges $i$, en altres casos, del batlle general o de procuradors territorials ${ }^{148}$. Fins $i$ tot, en casos excepcionals designa els oficials, posteriorment aprovats pel monarca, com succeix el $1350 \mathrm{amb}$ el veguer de Cerdanya i batlle de Puigcerdà ${ }^{149}$.

El conjunt d'actuacions, amb una forta estesa arreu dels comtats d'ordres, detencions, missives, citacions... ${ }^{150}$, popularitzen la governació, que troba, però, la major ressonància a través d'una elevada intervenció judicial, a voltes per delegació règia ${ }^{151}$, per bé que usualment per pròpia iniciativa, tant assumint casos especialment cridaners $^{152} \mathrm{com}$ afrontant tota mena de delictes: resistència a veguers, assassinats... ${ }^{153}$, amb una ingerència creixent $a m b$ el segle XIV, de la que deriven important penes pecuniàries tot imposant compositiones et avinencie i generant un ingrés prou ordinari com perquè hi intervingui la procuració reial ${ }^{154}$. Centrat a Perpinyà, el governador empra, si cal, la mateixa presó comuna a tots els oficials reials amb seu a la capital rossellonesa ${ }^{155}$.

Aquesta destacada actuació judicial ${ }^{156}$, també acull apel.lacions malgrat que a Perpinyà rau la cort d'apel.lacions més arrelada de Catalunya. La cort, dotada d'una plena capacitat d'actuació ${ }^{157}$, es desenvolupa amb tota normalitat en el sistema jurídic coetani. L'escrivania exerceix, per tant, una elevada activitat, presidida per l'scrivà del governador o del offici de la governación ${ }^{158}$, un notari que l'ha adquirida ${ }^{159}$. En tota

147 ACA, Cancelleria, regs. 960, fol. 51v; 961, fol. 132r.

148 Flocel SABATÉ, El vèguer a Catalunya. Anàlisi de la jurisdicció reial al segle XIV, tesi doctoral, Unviersitat de Barcelona, 1993, pp. 1066-1084.

149 ACA, Cancelleria, reg. 961, fol. 166r-v.

150 ACA, Reial Patrimoni, Mestre Racional 1522, fols. 323r, 338v, 344v, 347v, 353r; 1523, fol. $79 \mathrm{r}$; 1527 , fols. $284 \mathrm{r}-\mathrm{v}, 308 \mathrm{v}, 309 \mathrm{v} ; 1569 \mathrm{C}-2$, sense numerar; $1569 \mathrm{C}-3$, sense numerar.

151 ACA, Cancelleria, reg. 2111, fol 1v.

152 ACA, MR $1569 \mathrm{C}-2$, sense numerar.

153 ADPO 1B-210, fols. 35r-38v.

154 ADPO 1B-210, fols. 35r-36v.

155 Carcellarie gobernatoris, vicarii, baiuli, subbaiuli, capitis excubiarum et alcaldarum monetariorum ville Perpiniani, als que encara hi cal afegir els procuradors reials (ADPO 1B-186, fol. $45 r-v)$.

156 ADPO 1B-133, fol. 31v.

157 ADPO 1B-225, fol. 82r.

158 J. B. ALART, Documents sur la geographie historique du Roussillon, "Bulletin de la Société Agricole des Pyrénées-Orientales", 22 (Perpignan, 1876), p. 584.

159 ADPO 1B-120, fol. 19v. 
l'actuació jurídica i processal és imprescindible l'assessor. Per a unificar criteris en les altes instàncies judicials i evitar l'allargassament dels processos, el 1351 Pere III ordena que l'assessor del governador sigui alhora el jutge del patrimoni i el jutge de les apel.lacions ${ }^{160}$, amb una simbiosi que es respecta -offici de la assessoria del governador e del jutgat de les apellacions e del patrimoni- i es popularitza ${ }^{161}$. A més, el 1372 ell mateix rep ${ }^{162}$ el comissariat sobre l'aljama jueva perpinyanesa, que inclou les comunitats jueves d'ambdós comtats ${ }^{163}$-officium assessorie gubernatoris comitatuum Rossilione et Ceritanie una cum officie comissarii aljame iudeorum ville Perpiniani-, tal com es reitera ${ }^{164} i$ fins i tot s'hi aferma el 1387 en superar les protestes $^{165}$. La cura per la seva integritat moral i per la qualitat de la seva funció es pretén regular en imposar-hi les mateixes garanties que les corts de 1419 estableixen tant per a l'assessor del governador del Principat com per a la persona de l'assessor del portant veus de governador en los comtats de Rosselló e de Cerdanya ${ }^{166}$.

La cort del governador de Rosselló i Cerdanya no sols desenvolupa el registre de manaments i obligacions, amb la destacada actuació en establiment de paus, treves i seguretats, sinó que es converteix en un àmbit ben freqüentat per la sol.licitud de totes les tasques d'autenticació, tutoria —especialment de gent important, com en la tutela del petit Joan de Ribes el $1369^{167}$ - i fins i tot registre de crèdit. Sobretot aquesta incita, ja en el segle XV, a perfilar un propi collector de terços, cosa, però, que obre la via de l'oposició amb el govern de Perpinyà.

En l'àmbit executor, una inicial dotació de dos verguers es redueix a un el 1351, bé que tot seguit hi és afermat el porter. Tanmateix, la cort governativa perpinyanesa gaudirà d'un permament suport de les corts vicarials, amb un caràcter usual i corrent ben poc conegut en el Principat. Les corts vicarials assumeixen la realització i el cost

160 Quod assessor dicti gubernationis sit iudex patrimonii nostri dictorum comitatum et appellacionum (ADPO 1B-133, fol. 31v).

161 El 1373, per exemple, l'actuació del jutge d'apel.lacions s'expressa de consell de mossèn Jacme dez Monell, assessor de mossèn lo governador e jutge d'apellacions (ACA, Reial Patrimoni, Mestre Racional 1524, fol. 254v).

162 ACA, Cancelleria, reg. 1913, fol. $42 \mathrm{r}$.

163 Pierre VIDAL, Les juifs des anciens comtés de Roussillon et de Cerdagne, Editions Mare Nostrum, Perpignan, 1992, p. 28.

164 ACA, Cancelleria, reg. 1912, fol. 124r.

165 ACA, Cancelleria, reg. 1913, fol. $41 \mathrm{v}$.

166 Cortes de Cataluña, "Cortes de los antiguos reinos de Aragón, Valencia y Principado de Cataluña», XII, Real Academia de la Historia, Madrid, 1908, pp. 331-332.

167 ADPO 1B-120, fol. $2 \mathrm{v}$. 
de diverses activitats per encàrrec de la governació: persecucions d'inculpats ${ }^{168}$, afers jurisdiccionals ${ }^{169}$ i sobretot citacions a qui sigui obligat a què vengés davant lo senyor governador per alcunes coses ${ }^{170}$, incloent algun encolpat de diversos crims ${ }^{171}$, anar a Salsses per citar los cònsols del dit loch que vengessen davant lo governador per alscuns affers del senyor rey, trameses d'un saig al Voló, a Montesquiu e a la Rocha $e$ ad Argilers per citar los balles dels dits lochs que comperegessen davant mossenyer lo governador per alscuns affers del senyor rey ${ }^{172}$, anà a Baxàs ab letra del governador al rector del dit loch que vengués personalment per I greuge qui fahie a les regalies del senyor rey ${ }^{173}$ o qualsevol altre afer manat per la cort del governador ${ }^{174}$. Veguers $\mathrm{i}$ sotsveguers es converteixen en auxiliars a les ordres del governador, tant per aplicar les disposicions governatives encarades a imposar l'ordre, la pau o la seguretat ${ }^{175}$ com, també, per a vetllar els béns i les persones reials ${ }^{176}$. En aquest sentit, les corts vicarials, i les batliars amb competències en aquests casos, assumeixen el cost de crides encarades a pacificar o limitar conflictes de bàndols ${ }^{177}$. Fins $i$ tot les penes

168 El 13 de febrer de 1385 el lochtinent de veguer per manament de mossèn lo governador anà a Fforça Ral, castell roquer e envers aquells parts per serchar e pendre si pogués en Berthomeu Lunes, qui era fugit ab l'escarceller de la preson rial de Perpenyà, on stava pres, e dehie se que era fugit envers lo dit castell e encara que era dubte que no.s fos aquí recullet per tal com lo ffill del dit scarceller estava al dit castell. Dit d'altra manera: pujà lo dit lochtinent a Fforsa Rial per encalsar en Lunes qui era fugit de la presó ab l'escarceller, e mossèn lo governador mana-li que ell prengués lo ffill del dit scarceller qui era castellà de Força Reyal pensant-se que ell hi fos consentent que en Lunes fos dintre lo castell, e lo dit lochtinent puja-y ab si sinquesine a cavall e ab XX servents a peu (ACA, Reial Patrimoni, Mestre Racional 1525, fols. 64v-65r).

169 ACA, Reial Patrimoni, Mestre Racional 1522, fol. 344v.

170 ACA, Reial Patrimoni, Mestre Racional 1522, fol. 338v.

171 ACA, Reial Patrimoni, Mestre Racional 1522, fol. 353v.

172 ACA, Reial Patrimoni, Mestre Racional 1522, fol. 323r-v.

173 ACA, Reial Patrimoni, Mestre Racional 1525, fol. 76r.

174 ACA, Reial Patrimoni, Mestre Racional 1522, fol. $347 \mathrm{v} ; 1525$, fol. $74 \mathrm{v}$.

175 El 23 de febrer de 1385, l'onrat en Dalmau de Canet, lochtinent de veger de Rosselló per manament ab eyll ffet per lo noble mossèn Gilabert de Cruylles, governador de Rosselló e de Cerdanya anà al loch d'Argilers al qual loch segons que.s dehia s'era trobada una scala de fust dreta al mur dins la forrsa al qual loch lo dit lochtinent anà si ters a cavall e dos missatgés a peu per fer inquisició (ACA, Reial Patrimoni, Mestre Racional 1525, fol. 66r).

176 El 1373, de manament del governador e de son conseyll lo dit vager anà per los lochs hon se deya que la senyora duquessa devia passar per tall que.ls lochs desos scrits fossen ben provehits de viandes, de lits he de posades he mes per fer endressar los pons e.ls passes. Més endavant, el veguer anà, de manament ha eyll ffet per lo governador, a la senyora duquessa per tal com ardit hy havia per ço com companyes aguaytaven he ses fforssaven de dar dampnatge a la dita senyora perquè lo dit vaguer anà si Vle a cavall he VIII sags he $V$ macips de casa sua he ab I atsembla carregade d'armes ves les parts hon la dita senyora venia he acompanyà aquella entro que fos dins Perpenyà (ACA, Reial Patrimoni, Mestre Racional 1524, fols. 331r i 333r).

177 El setembre de 1387 de manament de mossèn lo governador es fa a Perpinyà, pagant a mitges el veguer i el batlle, una altra crida e prohibició sobre la guerra de l'ardiacha de Fonolledes $e$ d'en Amill de Perapertusa que alcuns hòmens d'armes e altres no gosaren entrar a la terra del Rey d França per dampnificar aquella (ACA, Reial Patrimoni, Mestre Racional, 1527, fol. 271v). 
capitals $^{178}$ són executades per les corts vicarials ${ }^{179}$ quan per molts e diverses maleficis e crims per ell comeses lo dit veguer per manament de lo governador féu penjar ${ }^{180}$. La centralització a Perpinyà imposa que l'ús afecti de manera més destacada la cort del veguer de Rosselló, no sols per les barreges de membres d'ambdues corts ${ }^{181}$ sinó perquè, en la pràctica, els oficials de la vegueria estan a disposició de governación ${ }^{182}$ i fins $i$ tot es desplaçaran saigs vicarials a altres demarcacions per a trasiladar presos a la capital ${ }^{183}$. A totes les vegueries, però, i de manera ben reiterada, el governador refia dels veguers per a la defensa de la frontera, tant per regonèxer les forsses ${ }^{184} \mathrm{com}$ per alertar dels perills ${ }^{185}$, tot avançant en les combinacions amb els capitans ${ }^{186} i$ assumint les incidències pròpies del veïnatge entre diferents reialmes ${ }^{187}$. En el mateix sentit, és a través de les corts vicarials que s'efectuen les crides governatives en matèria de defensa i provisionament, afectant a les recollides de persones 0 al trànsit i les vitualles ${ }^{188}$.

178 ACA, Reial Patrimoni, Mestre Racional 1569 C-2, sense numerar.

179 ACA, Reial Patrimoni, Mestre Racional 1569 C-3, sense numerar.

180 ACA, Reial Patrimoni, Mestre Racional 1527, fol. 310r.

181 El 1369 el regent de la vegueria de Rosselló, juntament amb el scriva e.ls saigs qui ab ell eren, de manament del governador anà a Elna ab en Johan Viga, porter del governador e ab XIIII missatgers per amenar pres en Pere Brandi ladonchs batlle ral d'Elna (ACA, Reial Patrimoni, Mestre Racional 1523 , fol. 79r).

182 El 4 de febrer de 1390 el lochtinent de procurador fiscal de la cort del veguer de Rosselló, per manament de mossèn lo governador e ab letra sua eren anats a Elna per pendre e menar pres I hom appellat Roquer de Barberà, lo qual se dehia que era anat a les companyes e que era spia lurs (ACA, Reial Patrimoni, Mestre Racional 1527, fol. 308v).

183 ACA, Reial Patrimoni, Mestre Racional 1527, fol. 284r.

184 ACA, Reial Patrimoni, Mestre Racional 1525, fols. 70v, 84r.

185 El 1385, per exemple, com mossèn lo governador hagués haut ardit que les companyes d'armes stranyes qui eren en Empurdà s'eren ajustades per tornar-se'n e devien passar per Rosselló, per so 10 dit Dalmau de Canet, lloctinent del veguer, per manament del governador anà per la vegeria per assabantar los lochs forts que.s gardassen bé, maiorment los lochs qui stan en la frontera e fer trenchar los passes. E anà ab si tres a cavall, so és, ell e Johan de Colunya, Pere Martra, saigs (ACA, Reial Patrimoni, Mestre Racional 1525, fol. 61).

186 ADPO 1B-163, fol. 31r.

187 Mossèn lo governador dels comtats de Rosselló tramet a P. Fabre de Perpenyà ab ses letres de crehença secretament donadora al dit P. Fabre hagués endreçades al dit lochtinent de veguer e al honrat en Guiu Bertran lochtinent de procurador Real en Cerdanya pe tant com se dehia lo dit mossèn lo governador havia çerts ardits de la part de Ffrança que lo castell de Bellver per algun apellat Garrot, fiyll den Garrot de Bellcayra en la terra de França, tant e consistent hun capellà e huna dona devia a breus dies ésser trasate liurat a home d'armes de la part de Ffrança perquè lo dit mossèn lo governador mana als dits lochtinents de veguer e de procurador reyal que ensemps ab lo dit $P$. Fabre anassen, retrassen e regonessen les forçes de Cerdanya en special aquella de Bellver e los informassen de les dites coses perquè lo dit lochtinent anà per los dits affers ensemps ab los dits lochtinent de procurador real P. Fabre, Jacme Bellcayre missatgé de la sua cort e Bernat Fabre scrivà (ACA, Reial Patrimoni, Mestre Racional, 1501, fols. 88v-89r).

188 ACA, Reial Patrimoni, Mestre Racional 1527, fol. 309v. 
Per la seva part, des de les corts vicarials, s'eleven al governador consultes, tant per a requerir ajut en disputes amb l'entorn nobiliari o amb les pressions municipals com davant dels diversos dubtes d'actuación ${ }^{189}$, alhora que serà el governador qui intervindrà més directament en les diferents problemàtiques durant la gestió de l'ofici vicarial ${ }^{190}$ o per raó de conflictes de competències i jurisdicció, com esdevé el 1434 entre el sotsveguer de Vallespir i el veguer de Rosselló entorn d'un crim comès a Sant Joan de Pladecorts ${ }^{191}$.

Es pretén que el conjunt d'activitats, i molt concretament les penes pecuniàries derivades de la pràctica judicial ordinària o extraordinària, permeti autoabastir les despeses governatives, inclòs els pagaments dels salaris, i que encara en derivi una part cap a la procuració o governació general.

Corresponent amb la seva alta posició, les corts governatives són les que, en la regulació de 1369 , tenen assignat el nombre més elevat de cavalls dels diferents àmbits de l'administració catalana, set per a la governació del Principat, dels quals dos són per al lloctinent de governador, i cinc per al governador dels comtats de Rosselló i Cerdanya $^{192}$.

\section{EL SOBIRÀ I LA TASCA GOVERNATIVA}

Els vicegerents de procuradors o els portantveus de governadors són, segons la pròpia denominació, representants del delegat reial superior. Però per la seva posició sobre el conjunt de Catalunya, pel mateix caire delegat del procurador i del governador i per la simbiosi entre aquest i la corona, mantenen una relació permanent i directa amb el sobirà. Assoleixen una posició per si mateixos, tal com reflectiran nombrosos tractaments protocolaris en afers jurisdiccionals, rera el procurador o governador general i per davant de veguers i batlles ${ }^{193}$. Les intervencions de procuradors i governadors generals destacats —els infants Alfons i Pere i els infants Joan i Martí194_ no eliminen la pròpia capacitat de vicegerents i portantveus, sinó que s'hi complementen. La co-

189 En encetar-se el segle XV, per exemple, el sotsveguer de Vallespir tramès de continent en G. Bertran a Perpenyà ab una letre requisitòria al governador e al vager de Rosselló que com lo dit sotsvager hagés inclusit lo dit $P$. Vesia a la glesia de Montferrer, qui ere home molt criminós de molts crims e de mort den capellà e de forsar fembres e altres malificis, que hagessen a dar al dit sotsvager consell, favor e ajuda e.Is dits governador e vager trameseren-hi dos saigs, atès el conflicte jurisdiccional esclatat amb el batlle i el poble de Montferrer (ACA, Reial Patrimoni, Mestre Racional $1569 \mathrm{C}-1$, fol. $4 v-5 r)$.

190 El governador intervé dins de la cort del veguer en casos com la pèrdua del segell: el 1385 s'efectuà una crida que feren solempnial ab trompes e tabals per manament del governador del segell reyall de la cort del dit veguer qui fo perdut per desaventura e per tal com se hac a mudar de necessitat fo cridat e de nou fo fet l altre sagell autèntich (ACA, Reial Patrimoni, Mestre Racional 1525, fol. 70r).

191 ACA, Reial Patrimoni, Mestre Racional 1569 C-3, sense numerar.

192 ADPO 1B-346, fol. 118r.

193 AHCB C-V, caixa 1, plec "Contra tonsuratos et personas eclesiasticas", per exemple.

194 AHMV, Llibre de Privilegis XXVII, pergami 497. 
muna actuació al servei de l'enlairamet del poder reial evita fricccions entre la procuració o la governació i el seu representant, bé que si apareixen és el mateix monarca qui hi arbitra, com s'esdevé el 1325 entorn del dret de rebre les cenes ${ }^{195}$.

L'elevada posició del governador i la plena imbricació amb la corona és plenament percebuda. El 1419 les corts generals exposen al rei que el portant veus de governador en Cathalunya (...), absent vós, senyor, e lo illustre primogènit vostre del Principat de Cathalunya, regeix la justicia en lo dit Principat ${ }^{196}$. Ell mateix assumeix que el seu deure és subditos regios in iure eorum debite confovere ${ }^{197} \mathrm{i}$ els jurats de Girona, en parlar d'ell al monarca el 1350, palesen el nítid lligam amb la corona en referir-s'hi com vostra portantveus de procurador ${ }^{198}$, tal com recull la pròpia titulació a la darreria del segle XIV: Raymundus Alamany de Cervilione, miles consiliarius et camarlengus serenissimi domini regis et pro eodem domino Cathalonie gubernator ${ }^{199}$.

Coherentment, el monarca, a més de comunicar nomenaments i designacions ${ }^{200}$, delega responsabilitats ja no sols en el seu procurador ${ }^{201}$, sinó directament en el vicegerent o portantveus ${ }^{202}$, de manera usual i no merament substitutòria per la minoria del titular de l'alta representació, tal com mostra, per exemple Jaume II davant de la petició dels consellers de Vic per a establir la taxació de les percepcions en les corts ordinàries ${ }^{203}$. El rei requereix el suport del vicegerent en les comissions per a la recuperació de les rendes reials ${ }^{204}$ o per a vetllar per la jurisdicció en els diferents indrets ${ }^{205}$, alhora que li cedeix la solució de conflictes jurisdiccionals o de tensions de veïnatge ${ }^{206}$. La confiança és plena, en tant que el sobirà li mana una actitud col.laboradora ${ }^{207}$ en afers que el preocupen força, com la participació en la repressió de les falsificacions de moneda ${ }^{208}$. En els problemes jurisdiccionals i en les necessitats d'arbitratges, tant per conflictes veïnals com per fisures municipals internes, és reiterada la delegació, especialment en existir-hi violències. Alfons el Benigne continua amb la mateixa política, mitjançant el vicegerent de Catalunya que sovint és in nostra curia presente i que pot rebre l'encàrrec de tractar crims com el comès el 1330 a Conill de Segarra, a partir de la informació facilitada pel veguer de Cervera a la cort reial ${ }^{209}$, o

195 ACA, Cancelleria, reg. 507, fol. 231v.

196 Cortes de Cataluña, "Cortes de los antiguos reinos de Aragón y Valencia y Prinicpado de Cataluña», XII, Real Academia de la Historia, Madrid, 1908, p. 332.

197 ACA, Diversos, Fons Institucionals, Governador General de Catalunya, reg. 1, fol. 3v.

198 AHCG I.1.2.1, lligall 5, llibre 4, fol. 52r.

199 ACA, Diversos, Fons Institucionals, Governador General de Catalunya, reg. 1, fol. $1 \mathrm{r}$.

200 ACA, Cancelleria, reg. 233, fols. 146v; 505, fol. 125r.

201 ACA, Cancelleria, reg. 528, fol. 251r.

202 ACA, Cancelleria, regs. 245, fol. 132v; 247, fol. 256v; 530, fol. $215 \mathrm{r}$.

203 AHMB, Llibre de Privilegis $X I X$, fol. $51 \mathrm{v}$.

204 ACA, Cancelleria, reg. 527, fol. 102v.

205 ACA, Cancelleria, reg. 236, fol. 173r.

206 AHCT, pergamins, caixa 2, 1305.

207 ACA, Cancelleria, reg. 241, fol. 45 r.

208 ACA, Cancelleria, reg. 239, fol. 207r.

209 ACA, Cancelleria, reg. 525, fol. 178r. 
atendre els problemes de jurisdicció exposats davant del monarca el 1334 pel veguer de Girona i Besalú entorn de Banyoles ${ }^{210}$ i respecte del vescomte de Cabrera ${ }^{211}$.

Les delegacions reials a l'òrbita de procuració general continuen, sobretot entorn a conflictes jurisdiccionals, veïnals $i$ de bàndols ${ }^{212}$, instant els oficials menors a prestarhi suport ${ }^{213}$. Precisament, al llarg del segle XIV, l'evolució dels oficials districtuals reials, cada cop més mediatitzats pels poders locals i amb greus dificultats per a traspassar guanys econòmics al monarca, inclina aquest cap a comissaris especials, alhora que el bloqueig d'aquests pels mateixos municipis estreteix la confiança vers el vicegerent o portantveus. Per això, en el privilegi que el 1339 impedeix durant vint anys l'actuació de comissaris a Girona i la seva demarcació, el monarca fa excepció del procurador general o el seu portantveus ${ }^{214}$, $i$ en les corts de 1353, en aprovar-se que al llarg d'un decenni el rei no crearà nous comissaris especials, s'especifica excepti procuratori Cathalonie et Gubernatori Rossillone et Ceritanie ${ }^{215}$.

El portantveus de governador esdevé el suport del monarca en requerir pressions -cas d'Anglesola el $1379^{216}$ — o directament intervencions armades -el suport al nou arquebisbe de Tarragona ${ }^{217}$ el $1386^{218}$ - Es qui pot negociar en delegació i nom del monarca, sobretot quan s'obvia el procurador o el governador general per minoritat o per protocol.larització, com es fa el 1398 arran de les disputes entre Tàrrega i Anglesola per l'ús de l'aigua ${ }^{219}$. En el mateix sentit, intervé de forma reiterada en els conflictes de veïnatge per afers jurisdiccionals i d'ús de recursos agropecuaris ${ }^{220}$. Amb aquestes intervencions i pacificacions, la governació aplica -i alhora proclama, reivindica $\mathbf{i}$ consolida - l'autoritat reial en la convulsa sortida del segle XIV.

Aquesta identificació és ben copsada pel poder municipal. El 1383 un govern de Barcelona molt queixós amb el monarca i el governador general, als qui considera responsables de la forta inestabilitat existent als carrers de la ciutat arran de les concessions de guiatges, remissions, llicències i canvis de fur que impedeixen l'eficàcia

210 ACA, Cancelleria, regs. 528 , fol. $246 r ; 529$, fol. 6 r.

211 ACA, Cancelleria, reg. 528, fol. 251r.

212 AHCT, Cartes Reials, 4.

213 ACA, Cancelleria, reg. 1042, fol. 142v.

214 AHCG XVIII, Llibre Verd, fol. 67-68v.

215 AHCB, C-V, caixa 1, plec "de comissaris», sense numerar; AMC, Llibre de Privilegis de Camprodon, fol. 22v.

216 ACA, Cancelleria, «Papeles por incorporar», 1379, sense numerar.

217 Ezequiel GORT, Els senyors feudals de Reus, Carrutxa, Reus, 1989, pp. 48-50; Exequiel GORT, Pere de Luna i la senyoria de Reus, Patronat del Castell, Reus, 1987, pp. 19-20.

218 Bernat de Vilademany, cavaller, dient-se portant veus de Governador de Cathalunya, ab molta companya de cavall e de peu sie vengut al loch de Constentí situat en lo Camp de Terragona manant als habitants d'aquell de part del senyor Rey e requerint-lurs que obeyssen en spiritual e temporal al Cambrer de Terragona (AHPB, Notari Joan Eiximenis, lligall 15, «Protestacionum et sentencialiter liber (1377-1389)", sense numerar).

219 AHCT, caixa 13, pergamí 1398.

220 AHCT, Administració municipal, correspondència, cartes reials, núm. 6. 
de la justícia ordinària, eleva la protesta al rei, però com a mesura immediata demana que us placia de manar al portant veus de governador que venga e stia açí per provehir sobre les dites coses ab nosaltres ensemps ${ }^{221}$.

En aquesta posició intermèdia, durant el període de governacions territorials (13441347) els governadors accentuen la funció transmissora de la corona, amb una reiterada tasca en transmissió de les indicacions reials pel que fa a nomenaments 0 disposicions als altres oficials reials de la demarcación 222.

Als comtats de Rosselló i Cerdanya, la relació entre el monarca i el governador és permanent i regular. L'alt oficial esdevé la màxima representació de la corona tothora present als comtats. De manera protocol.lària, en cada actuació jurisdiccional a la zona el rei es remet primer al governador $i$, en segon lloc, als veguers i després als batlles. El monarca el manté al corrent de les concessions de privilegis ${ }^{223}$, les creacions de comissions $^{224}$ o els atorgaments d'oficis ${ }^{225}$ i s'hi relaciona pels més variats afers de govern ${ }^{226}$ : el 1360 , per exemple, li escriu contrariat perquè a les cort vicarials es continuen respectant antics usos propis del regne de Mallorca, a la vegada que vol revocar guiatges procedents de l'època de guerra i es preocupa per la situació del patrimoni i la jurisdicció en les darreres cessions ${ }^{227}$. Com a màxim responsable reial, el sobirà li confiarà que vetlli afers com l'aplicació de les mesures de control dels oficials districtuals ${ }^{228}$, es refiarà de la seva tasca en la contenció i informació de la frontera ${ }^{229}$, li encarregarà solucionar conflictes jurisdiccionals, com el 1387 davant l'abat de Cuixà ${ }^{230}$, i l'advertirà de les remissions i acords sorgits directament de la cort reial, com s'esdevé el 1381 en les remissions als homes de Perpinyà ${ }^{231}$, coses que s'afegeixen a la reiterada delegació de casos arribats a la cort reia ${ }^{232} \mathrm{i}$ afers ben diversos, com l'encàrrec efectuat el 1397 de vetllar pel bon trasllat d'un nou petit lleó per a la reial casa de lleons de Perpinyà ${ }^{233}$. Tot plegat evidencia el governador dels comtats com espill de la capacitat jurisdiccional del monarca, raó per la que el governador general, el 1368, preocupat per servar el caire reial de la vegueria natural de la vall de Ribes, aprofita els conflictes entre aquesta i Puigcerdà per a manar al governador que cada any s'hi

221 AHCBa, B-VI, llibre 1, fols. 139v-140r.

222 AHCG XVIII, Llibre Vermell, fol, 8v.

223 ADPO 1B-163, fol. 9 r.

224 ADPO 1B-163, fol. 12r.

225 ADPO 1B-163, fol. 21r; ACA, Cancelleria, reg. 1914, fols. 60v-61r.

226 AHCP, Llibre de Provisions Reials, fol. 36r-v.

227 ADPO 1B-346, fols. 45r-52v.

228 ACP AA5, fol. 60r-v.

229 El 1391 un correu del governador encalça el monarca per Barcelona i Saragossa per a informar-lo de societatibus sive de les companyies que redecebant de Ytalia et minabant ingredi in terram domini regis (ADPO 1B-172, fol. 2v-3r).

230 ACA, Cancelleria, reg. 1944, fol. 2 r.

231 ACP, AA5, fols. 34v-35r.

232 ACA, Cancelleria, reg, 2111, fol. 1v.

233 ACA, Cancelleria, reg. 1944, fol. 108v. 
desplaci si més no un cop per aplicar justícia allà mateix ${ }^{234}$. La delegació del governador general a mans del governador dels comtats es reitera, tal com es veu el 1372 quan, estan en la vila de Perpenyà, hagués citats alscuns qui eren inculpats de manepolis e de congregacions de dret prohibides e encara alscuns qui eren acordats e no eren anats en l'armada, el senyor duch hagués açò assí reservat e en lo pertinent de Perpenyà ho hagués comès al governador, el qual se n'ocuparà mitjançant l'habitual col.laboració amb el veguer ${ }^{235}$.

En tots els casos, el fet que la divisió entre les funcions governatives i les de la corona no sigui competencial sinó jeràrquica facilita relacions successives, tant en apel.lacions que recorren al sobirà després d'haver passat per la cort governativa, com, també, correccions per part del sobirà ${ }^{236}$. El parer reial pot fer reconsiderar nomenaments ${ }^{237}$ i decisions ${ }^{238}$ o pot ser sensible a queixes com l'exposada pel govern municipal de Puigcerdà el 1379 contra l'actuació judicial del governador i el seu assessor ${ }^{239}$. La mateixa relació pot comportar alguns escadussers conflictes, especialment quan el monarca extreu casos reservats prèviament pel governador. Es el que succeeix el 1392, quan el veguer de Girona procedeix contra Guillem Ramon de Lloret arran d'una marca requerida per les universitats de Biert, Canet i Montcal: el cas és asssumit pel governador a petició del mateix interessat, que al.lega pobresa, plantejament, però, que incita la intervenció del monarca sota la invocació de retenir en regalia els casos de persones miserables ${ }^{240}$.

La cort governativa no sols assumeix aquestes correccions sinó que moltes vegades cerca la concordança amb el monarca abans de pronunciar-se, com fa el 1322 a Vic amb motiu de la intervenció per la reforma et concordie inter maiores et minores Civitatis $\mathrm{Vic}^{241}$. A la sortida del segle es reiteren les enteses i combinacions entre les corts del governador i del monarca, sobretot en els casos de remissions generals, superant inicials divergències respecte de qui l'aplica. Ja en preparar-les la tresoreria reial estableix ponts entre la cort reial i la governativa ${ }^{242}$, i en diversos casos la percepció també es comparteix: el 1377, sota l'excusa d'un assassinat, s'imposa als targarins una remissió general de 3000 sous, dels quals 1700 seran pel rei i 1300 pel governador ${ }^{243}$.

234 Ferran VALLS y TABERNER, Privilegis i ordinacions de la Vall de Ribes, Universitat de Màlaga, Saragossa, 1992, p. 569.

235 ACA, Reial Patrimoni, Mestre Racional, 1523, fols. 72v.

236 ACA, Cancelleria, regs. 527, fol. 102v; 2005, fol. 17r-v.

237 ACA, Cancelleria, reg. 507, fols. $218 \mathrm{v}-219 \mathrm{r}$.

238 ACA, Cancelleria, reg. 246, fol. 242r.

239 AHCP, Llibre de Provisions Reials, fols. 65v-66v.

240 ACA, Cancelleria, reg. 2011, fols. $17 \mathrm{v}-28 \mathrm{r}$.

241 ACA, Cancelleria, reg. 247, fol. 44v.

242 Flocel SABATÉ, L'augment de l'exigència fiscal en els municipis catalans al segle XIV: elements de pressió i de resposta, "Col.loqui Corona, municipi i fiscalitat a la baixa edat mitjana (Lleida, 1995)" Institut d'Estudis llerdencs, Lleida, 1997, pp. 429-430.

243 AHCT, pergamins, caixa 10, 1377. 


\section{EL PODER MUNICIPAL I L'EXERCICI GOVERNATIU}

El procurador o el governador general i, més específicament, els seus vicegerents o portantveus a Catalunya, són vistos, des dels governs locals, com l'alta magistratura propera a la corona, raó que facilita un tracte usual. Els municipis requereixen la seva intercessió per a protegir els drets i interessos de la localitat i dels seus habitants com fa la ciutat de Lleida el 1340 davant del procurador general per a protegir un conciutadà contra el veguer de Tàrrega ${ }^{244}$ - Igualment, es recorre a l'ofici governatiu per a suturar fractures internes, de caire estamental ${ }^{245}$, social o per raó de bàndols ${ }^{246}$. S'espera, fins i tot, que la seva intercessió contribueixi a rectificar decisions reials, com és el cas de la ciutat de Barcelona el 1362 en requerir l'ajut de l'honrat n'Ombert de Bellestar, lochtinent de portant veus de Governador en Cathalunya, contra l'aplicació de la modificació dels límits de la demarcació concedida pel monarca a la vegueria de Vallès ${ }^{247}$, o el 1392, en haver de corregir les excarcelacions dictades pel sobirà en una ciutat prou convulsionada ${ }^{248}$. Esdevé usual consultar els diferents afers de govern, segons practica el municipi de Girona el 1342 en adreçar-se a Ramon de Copons, en el context de la guerra amb el titular de Mallorca, per a tractar sobre la protecció de la ciutat $i$ instar el revocament de l'host convocada pel sotsveguer ${ }^{249}$. L'envigoriment del governador de Catalunya amb l'avenç del segle XIV accentua aquest tipus de tracte ${ }^{250}$ normalitzant-hi la relació: quan el 1393 el govern de Barcelona accepta el veguer entrant ho notifica al rei, a la reina i al governador ${ }^{251}$.

Alhora, la mateixa resistència que els municipis oposen a les exigències reials en matèria fiscal i militar es reprenen enfront dels representants governatius ${ }^{252}$, tal i com es reitera en les exigències de convocatòria d'host per part de viles com Tàrrega ${ }^{253} 0$ l'Arboç ${ }^{254}$. L'oficial districtual sol ocupar la pitjor posició en aquests casos, com li succeeix al veguer de Lleida quan el 1340 es troba entre l'ordre del procurador general per a convocar l'host i la taxativa oposició municipal, que amenaça amb apel.lar davant del sobirà ${ }^{255}$. De fet, el governador pretén intervenir en els diferents indrets i per això extreu

244 AML, Secció de Consells Generals, A-840, fols. 35r-36r.

$245 \mathrm{AHCO}$, fons notarial, secció Besalú, reg, 285, sense numerar.

246 AHMV, libre de Privilegis II, pergamí 34.

247 AHCBa, Fons municioal, B-I, llibre 21, fol. 44r.

248 Manual de novells ardits, vulgarment apellat dietari del antich consell barceloní, I. Frederich Schwartz i Luna i Francesch Carreras i Candi, eds., Ajuntament de Barcelona, Barcelona, 1892, p. 32.

249 AHCG I.1.2.1, lligall 1, llibre 2, fols. 43r-v, $51 \mathrm{v}$.

250 AHCC, Llibre de Consell, 1401, fol. 84r.

251 AHCBa, Fons municipal B-I, llibre 25, fol. 32r.

252 ACA, Cancelleria, Varia, reg. 275, sense numerar.

253 AHCT, llibre del consell 4, fol. 31r, 69v.

254 ACA, Cancelleria, reg. 2014, fol. $8 \mathrm{r}$.

255 AML, Secció de Consells Generals, A-840, fol. 56r. 
els casos endegats per l'oficial ordinari256 o es fa ajudar per aquest en l'aplicació de justícies ${ }^{257}$.

Precisament, aquest caire adoptat per l'ofici governatiu trobarà el seu principal blasmador en el poder municipal. L'afermament de la capacitat governativa, mitjançant la intervenció en afers jurisdiccionals, col.lideix amb uns poders locals defensors acèrrims d'uns oficials $i$ d'unes demarcacions ordinàries coincidents amb els propis radis d'emergència socioeconòmica. La topada, doncs, és immediata. Ja en el tombant del segle XIII al XIV els municipis es queixen de la intervenció distorsionadora del procurador: els paers de Cervera exposen al monarca que l'explícita ordre reial contra un bandejat no ha pogut ésser aplicada pel veguer perquè l'inculpat s'ha refugiat en els dominis baronials dels Queralt, d'on ha sortit immune perquè 10 noble en Ramon Folch (l')absolvé així com a procurador ${ }^{258}$.

A aquesta situació s'afegeix l'avocació de causes judicials, que moltes vegades juga a favor de poderosos que així són extrets d'una jurisdicció ordinària que els seria adversa, tot contribuint, alhora, a nodrir econòmicament la cort governativa i a desprestigiar l'actuació dels ordinaris. Els governs locals s'oposen a les intervencions extraordinàries i voldrien que en la pròpia demarcació, com expressa el govern targarí el 1343, inquisidors del seynor rey o lo seynor infant e procurador seu ne sos inquiridors no hi poguessen enquerir ${ }^{259}$. Les queixes municipals van articulant el cos legislatiu de les corts generals al respecte: el 1333 s'impedeixen les execucions aplicades sine consilio vicarii curie vel baiuli iudicis ordinarii vel assessoris illius $10{ }^{260}$, el 1350 la ciutat de Barcelona acusa la ingerència judicial en aers criminals del lavors procurador general de Cathalunya ${ }^{261}$, el 1353 es limita durant un decenni al governador $i$ al vicegerent a tractar casos només allà on estigui, havent de traspassar-los als ordinaris en abandonar l'indret ${ }^{262}$, plantejament definitivament imposat el $1359^{263}$. Amb aquestes limitacions, el governador pot assumir qualsevol causa judicial, tal com li reconeix Joan I el $1395^{264}$.

256 AHMV, Llibre de Privilegis IV, pergamí 68.

257 AHCTE, Clavari, llibre 27, p. 110.

258 ACA, Cancelleria, "Papeles por incorporar», Cervera, sense numerar.

259 AHCT, Llibre del Consell 2, fol. 44r.

260 Cortes de Cataluña, "Cortes de los antiguos reinos de Aragón y Valencia y Principado de Cataluña", I, Real Academia de la Historia, Madrid, 1896, p. 305.

261 Cortes de Cataluña, "Cortes de los antiguos reinos de Aragón y Valencia y Principado de Cataluña», I, Real Academia de la Historia, Madrid, 1896, pp. 430-431.

262 Cortes de Cataluña, «Cortes de los antiguos reinos de Aragón y Valencia y Principado de Cataluña», XII, Real Academia de la Historia, Madrid, 1908, p. 434.

263 Cortes de Cataluña, "Cortes de los antiguos reinos de Aragón y Valencia y Principado de Cataluña", II, Real Academia de la Historia, Madrid, 1899, pp. 44-45; Constitucions y altres drets de Cathalunya, llibre 1, títol XXXXI. II (Joan Pau Martí y Joseph Llopis, estampers, 1704; ed. facsímil: Departament de Justícia de la Generalitat de Catalunya, 1995, llibre I, pp. 102-103).

264 ACA, Cancelleria, reg. 1916, fol. 137v. 
L'actuació judicial, juntament amb la usual intervenció governativa en les crisis internes de la convivència local ${ }^{265}$, justifica l'aplicació de remissions generals a poblacions senceres sacsejades per les diverses fractures que esberlen els municipis a la segona meitat del segle XIV, afectats per bàndols, tibantors estamentals, tensions socials, veïnatges difícils i una forta exigència fiscal. Alhora que els governs locals acusen el monarca d'agreujar les dificultats amb les seves demandes ${ }^{266}$, la governació insisteix en aplicar unes remissions generals, preparades per la pròpia cort en relació amb la tresoreria reial sense dissimular que, ultra els fets concrets, es remenen antigues causes i velles trames tot calculant quina remissió es podria demanar no pas en funció de la gravetat del pretès delicte sinó de la capacitat de pagament de cada indret, amb l'afany d'aconseguir que d'aci exiran molts diners ${ }^{267}$. Amb aquesta actitud, en el darrer quart del segle XIV, les remissions aplicades per la governació són nombroses, redimint alteracions de l'ordre o desobediències col.lectives arreu del país, com la capcione seu resistencia de Reus al veguer de Tarragona el $1378^{268}$, els redeimes aplicats sense permís a Olot el $1379^{269}$ o el suport atorgat a bandejats a Sabadell el $1396^{270}$, entre molts alres. La concessió sol fer salvetat dels crims considerats més greus -lesa majestat, traició, heretgia, sodomia, falsa moneda i trencament de camins-i a voltes adopta combinacions que deixen la porta oberta a noves intervencions: el 1400 a Torroella de Montgrí per 300 florins d'or el governador redimeix la població però n'exclou uns acusats concrets i encara permet la continuació de processos endegats pel veguer de Girona ${ }^{271}$.

Així, de les remissions pronunciades pel procurador general arran d'afers concrets en el primer terç de segle ${ }^{272}$ es passa per les aplicades a mitjan segle $e^{273} \mathrm{i}$ es culmina en una veritable exigència fiscal encoberta ${ }^{274}$, també exercida pel monarca, i que el municipi col.loca a costat d'altres elements que proporcionen guanys crematístics a la corona i a la governació a canvi d'agreujar els eraris municipals i de desacreditar els sistemes judicials ordinaris. Aquí es situen, procedents de la cort reial o governativa, els guiatges i les licències, que permeten ridiculitzar les actuacions dels ordinaris contra personatges concrets $\mathbf{i}$ inutilitzar prohibicions municipals com les reiterades sobre

265 AHMV, Llibre de Privilegis XIX, fol. 165r.

266 ACA, Reial Patrimoni, Mestre Racional 372, fol. 42r.

267 ACA, Cancelleria, «Papeles por incorporar», 1379, sense numerar.

268 AHCR, pergamins, carpeta Comú 19, núm. 20; caperta Comú 20, núm. 86.

269 AHCO, pergamins, sèrie A, núm. 429.

270 AHS, pergami 25.

271 AHMTM, pergamí 40.

272 ACV, Calaix 37, Privilegis i Estatuts III, núm. 50; Gener GONZALVO, Josep HERNANDO, Flocel SABATÉ, Max TURULL, Pere VERDÉS, Els llibres de privilegis de Tàrrega (1058-1473), Fundació Noguera, Barcelona, 1997, pp. 120-121, entre altres exemples.

273 AHCBe, Llibre de Privilegis, plec núm. 8.

274 Flocel SABATÉ, L'augment de l'exigència fiscal en els municipis catalans al segle XIV: elements de pressió i de resposta, "Col.loqui Corona, Municipis i Fiscalitat a la Baixa Edat Mitjana (Lleida, 1995)», Institut d'Estudis llerdencs, Lleida, 1997, pp. 426-430. 
limitació en l'ús d'armes. Entre les concessions del governador i la indignació municipal, l'oficial ordinari es sol trobar atrapat al mig, com li succeeix al veguer de Barcelona el 1395 quan el govern local l'insta a no reconèixer les licències atorgades pel governador ${ }^{275}$. Els municipis també blasmaran els cada cop més creixents canvis de fur, mitjançant els quals la jurisdicció ordinària es troba irremeiablement blocada quan, en pretendre procedir contra algú, aquest, per gràcia reial degudament pagada, pot esgrimir privilegi de pertànyer a un altre fur personal, com pot ser l'exclusiva jurisdicció del governador.

Davant de tot això, el poder local pretén imposar una concepció de jurisdicció reial identificada no pas amb l'arbitrarietat del monarca i dels seus alts oficials sinó amb un corpus comú de legalitat perfilat per les Constitucions aprovades en Corts, els Usatges de Barcelona i el conjunt de privilegis locals ${ }^{276}$. Des d'aquesta proposta, els municipis, especialment els més poderosos, s'enfrontaran al monarca ${ }^{277}$, parlant amb la vostra reverència i salva reverència de la vostra reyal magestat, i també, però més abrivadament, al governador.

A la sortida del segle XIV el clima de tensió entre els municipis i el governador pren cos entorn de diversos estímuls, com a Vic, on el 1399 el governador acusa els magistrats locals d'invair competències reials en una indeguda convocatòria d'host ${ }^{278}$. Alhora, des del costat municipal, es pot al.legar parcialitat en l'oficial governatiu i obtenir del rei la inhibició de la seva actuació en favor dels ordinaris, tal com aconsegueix Tàrrega el 1370 respecte del portantveus de governador Guillem de Guimerà 279 o Olot el 1408 vers Albert Vilanova, lloctinent del governador de Catalunya ${ }^{280}$.

La condició baronial del governador comporta noves vies de tensió. Ja en el tombant del segle XIII al XIV la posició del vescomte de Cardona com a procurador l'aboca a contradiccions en la relació de poblacions com Cervera i Manresa amb dominis cardonencs. Conflictes notoris, com els problemes jurisdiccionals entre el veguer reial

275 Fo concordat $e$ deliberat e encara consellat al veguer aquí present, per los consellers, que no servàs I manament que mossèn Ramon Alemany Governador de Cathalunya ab letra signada de sa mà li havia fet que no levàs les armes a l convers de casa sua ne a ll altres qui.l acompanyassen, com lo dit governador lus n'agués dada licència per certes rahons, car aparia als dits consellers $\varepsilon$ consell que li dit manament del dit Governador portàs en manera e en forma e en altra manera torbàs to bon estament de la ciutat (AHCBa, Fons municipal, B-1, libre 27, fol. $111 \mathrm{rm}$ ) .

276 Flocel SABATÉ, El poder reial entre el poder municipal $i$ el poder baronial a la Catalunya del segle XIV, «XV Congreso de Historia de la Corona de Aragón (Jaca, 1993)», tomo I, volumen 2, Gobierno de Aragón, Zaragoza, 1996, pp. 339-341.

277 AHCG 1.1.2.1, lligall 2, llibre 1, fol. 46r-v; AHCBa Fons Municipal B-VI, llibre 1, fols. 139v140 ; llibre 2, fol. 3r.

278 AHMV, Llibre de Privilegis VI, pergamí 112.

279 La condició hospitalera de Guillem de Guimerà el convertia en suspitós de parcialitat en conflictes entre Tàrrega i indrets hospitalers per raó de pastures (Gener GONZALVO, Josep HERNANDO, Flocel SABATÉ, Max TURULL, Pere VERDÉS, Els llibres de privilegis de Tàrrega (10581473), Fundació Noguera, Barcelona, 1997, pp. 435-458).

280 AHCO, pergamins, sèrie A, núm. 224. 
cerverí i el batlle cardonenc de Tarroja, amb homeyers impunes entremig ${ }^{281}$, evidencien una creixent tensió entre el poder baronial i el poder municipal de jurisdicció reial que aconsella separar l'alta representació del monarca i l'òrbita nobiliària. La consolidació de l'ofici en una franja de petits i mitjans barons propers a la corona estalvia greus confrontacions, però aquestes en part retornen a partir, sobretot, del darrer quart del segle XIV. El 1380 la ciutat de Barcelona treu l'host contra Querol, faciendo execucionem contra nobilem Raymundum Alamanni de Cervilione ${ }^{282}$, governador de Catalunya, de la mateixa manera que el 1430 ho farà Perpinyà contra Millars, possessió de Ramon de Perellós, nebot del governador dels comtats de Rosselló i Cerdanya ${ }^{283}$. Alhora, els municipis tractaran de fer valer les limitacions legals a les pretensions del governador. Tortosa forçarà que les seves intervencions estiguin acompanyades de l'aprovació local ${ }^{284} \mathrm{i}$ limitarà les actuacions governatives com també cenyeix les reials mitjançant la invocació de la pròpia capacitat sobre el terme ${ }^{285}$. Es, però, la primera població catalana qui encapçala una oposició més contundent contra el governador, tant per gaudir d'una força superior com per invocar una elevada ingerència i transtorns a causa de suportar perllongades estades del governador, raó per la que el 1396 Martí I recomenarà a l'alt oficial que no interfereixi en els guiatges i que deixi actuar prèviament al veguer ${ }^{286}$. Arreu, però, el governador pretendrà afermar la capacitat d'intervenció a partir d'aferrar-se a les raons i subterfugis jurídics, tal com fa amb la proliferació del carreratge a favor de Barcelona ${ }^{287}$, invocat, per exemple, per a extreure un pres d'Igualada el 1399, malgrat la forta i estèril protesta dels jurats de la vila ${ }^{288}$.

Tota aquesta evolució es viu de forma similar però matisada als comtats de Rosselló i Cerdanya. En aquests, l'àmbit propi afermat pel governador li facilita tant la sincronització amb la corona com una receptivitat popular. Encerta així un espai propi que li estalvia inicials oposicions $i$, aliè a limitacions com les que des de 1359 afecten a l'homòleg del Principat, es fa portar causes a Perpinyà per les corts vicarials ${ }^{289}$, en ocasions en judica d'altres en desplaçaments ${ }^{290}$ i fins i tot a inicis del segle XV avoca molts casos d'assassinat, com fa al Baridà tot continuant processos endegats pel sotsveguer ${ }^{291}$.

281 ACA, Cancelleria, Varia, reg. 254, fol. $1 \mathrm{r}-\mathrm{v}$.

282 Crònica del racional de la ciutat de Barcelona (1334-1417), "Recull de Documents i Estudis", I/1 (Barcelona, novembre 1921), pp. 154-155.

283 J. B. ALART, Éphémérides des Pyrénées-Orientales. 15 Janvier, "L'Écho de Roussillon", 24 (Perpignan, 15 janvier, 1865), p. 1.

284 AHCTE, governador, 14.

285 Flocel SABATÉ, El veguer i la vegueria de Tortosa i Ribera d'Ebre al segle XIV, "Recerca", 2 (Tortosa, 1997), p. 141.

286 ACA, Cancelleria, reg, 2217, fol. 144r.

287 Maria Teresa FERRER, Projecció exterior, «Història de Barcelona», 3, Jaume Sobrequès, dir., Fundació Enciclopèdia Catalana - Ajuntament de Barcelona, Barcelona, 1992, pp. 361-365.

$288 \mathrm{AHCl}$, Fons municipal, Llibre de Privilegis, fols. 56r-57r.

289 ADPO 1B-120, fol. 3r.

290 ACA, Reial Patrimoni, Mestre Racional 1501, fulls solts sense numerar.

291 ADPO 1B-210, fols. 35r i ss. 
Tanmateix, el propi arrelament de la cort governativa esdevé conflictiva pels municipis, especialment per la capital, Perpinyà, que veu desviar una creixent activitat - tutories, asseguraments, registre de crèdit...- vers la cort del governador en comptes de la batliar considerada com a pròpia. Les protestes municipals s'incrementaran amb l'afermament governatiu, raó per la que el 1452 el rei anul.la el recentment designat collector de terços. Ja a la sortida del segle XIV la mateixa consolidació governativa atreu reiterats canvis de fur ${ }^{292}$, que comporten el principal punt de fricció amb el govern local.

A les altres seus demarcacionals les queixes es centren en l'avocació governativa, tal com s'evidencia a Vilafranca de Conflent i, encara més, a Puigcerdà. El 1379 el govern consolar d'aquesta descriu al rei l'actuació judicial del governador com gravosa per a la població, amb massa breus e injustes dillacions als delats e que abans que./s admeten a defensions les hagen a publicar la enquesta ${ }^{293}$. Des de Puigcerdà no agrada ni el lligam amb Perpinyà inherent al governador ni la ingerència en el control vilatà sobre la demarcació cerdana. Per això, el 1428 la vila aconseguirà que el rei limiti la intervenció del governador en la vegueria de Cerdanya a una prèvia autorització del govern local ${ }^{294}$.

\section{L'ACTUACIÓ GOVERNATIVA I ELS ÀMBITS DE JURISDICCIÓ BARONIAL}

La funció governativa representa el poder reial sobre el conjunt de Catalunya. En coherència, es farà portaveu dels afanys de preeminència del sobirà, vehicle de les estratègies que hi caldrà teixir i, també, receptacle dels rebutjos expressats per una noblesa que pretén aplegar força i tradició per a sustentar la pròpia capacitat.

La posició immediata a la corona propicia un accés dels barons a l'alt oficial governatiu per a cercar intercessió pels propis interessos, sempre en funció de la capacitat d'accés i d'incidència. La causa més corrent en mobilitzar la queixa dels nobles al llarg de tot el període, tant al Principat com als comtats de Rosselló i Cerdanya, és la consideració que els oficials districtuals reials han invaït indegudament jurisdicció baronial, en general al.legant persecució de malfactors i normalment al front de l'host, tal com a la primera meitat del segle XIV es reitera als comtats davant del lloctinent del rei de Mallorca ${ }^{295} \mathrm{o}$ al Principat en front del vicegerent $\mathrm{o}$, en el seu moment, dels governadors territorials ${ }^{296}$.

En realitat, els conflictes de jurisdicció regionals comporten el ressò de la pugna entre el poder baronial $\mathrm{i}$ el poder municipal pel control dels ressorts socioeconòmics

292 El 1395, per exemple l'scriva maior de la procuració reyal, Joan Colom, amb la seva família, obté privilegi reial per dependre del fur del governador i no pas de la del batlle, a qui li correspon la jurisdicció ordinària a Perpinyà (ADPO 1B-163, fol. 74r-v).

293 AHCP, Llibre de Provisions Reials, fols. 65v-66v.

294 Salvador GALCERAN, Els privilegis de Puigcerdà, "ler Congrés Internacional d'història de Puigcerdà (juliol, 1977) », Institut d'Estudis Ceretans, Puigcerdà, 1983, p. 128.

295 ADPO 1B-58, plec sense numerar, full sense numerar.

296 AHCG I.1.2.1, lligall 1, llibre 1, fol. 118v. 
d'un mateix espai a partir del domini i de l'atracció sobre una idèntica població. És el poder municipal qui empeny les actuacions del veguer i qui formula una pretesa simbiosi entre els propis interessos i l'afany reial d'afermament ${ }^{297}$. Per això, els mateixos governs locals que es resisteixen a convocar l'host per manament reial no dubten a mobilitzarla quan cal reivindicar els propis interessos sobre un veïnatge hostil, i en aquests casos convé el suport governatiu, com en la significativa anada, el 1343, de Girona contra Foxà ${ }^{298}$. Els municipis fins $i$ tot sol.licitaran a la corona que la figura governativa aplegui un reforç d'hosts reials contra domini baronial, com es demana des de Girona contra el vescomtat de Cabrera el $1336^{299}$. La simple presidència del governador ja es considera prou imbuída del suport del poder reial, com es diu el setembre de 1395, quan l'host de Barcelona es desplaça contra el castell del Far per raó de les violències senyorials del senyor del lloc, Riambau de Corbera, presidida per los nobles en Ramon Alemany de Cervelló (el governador) e mossèn Ombert des Fonollar, veguer de la ciutat e per los honrats Concellers de Barcelona ${ }^{300}$. En aquest context, en l'entesa finisecular entre municipis i monarquia per a la redempció jurisdiccional dels indrets cedits per la corona durant les dècades anteriors a carta de gràcia, el governador hi desenvolupa un paper de suport i, si cal, de coerción ${ }^{301}$.

En realitat, el representant del procurador o del governador general participa de les mateixes iniciatives reials per a fomentar el poder del sobirà i acotar la capacitat nobiliària. La posició superior del monarca és emprada per a oferir-se en arbitratges que, si més no, afermen la preeminència i la capacitat de penetració. Així es fa a Vic, entre el bisbe i els Montcada el $1304^{302}$ o a Gerri, el 1344, en la més difícil negociació entre el comte de Pallars i l'abat ${ }^{303}$. Un objectiu similar també batega, a la segona meitat de segle, en les intervencions per a pacificar ${ }^{304}$ conflictes de bàndols urbans fortament barrejats amb les tensions d'un espai rural fragmentat jurisdiccionalment $i$ en el que el poder reial cerca vies de penetració305.

La invocació de les regalies justifica reiterats enfrontaments per a servar àmbits exclusius per a la jurisdició reial. Es el vicegerent qui el 1318 es mobilitza contra el

297 Flocel SABATÉ, El poder reial entre el poder municipal i el poder baronial a la Catalunya del segle XIV, «XV Congreso de Historia de la Corona de Aragón (Jaca, 1993)», tomo I, vol. 2, Gobierno de Aragón, Zaragoza, 1995, pp. 337-341.

298 AHCG 1.1.2.1, lligall 5, llibre 1, fol. 14r.

299 AHCG 1.1.2.1, lligall 2, llibre 3, fol. 4r.

300 Manual de Novells ardits, vulgarment apellat Dietari del Antich Consell barceloní, I, Frederic Schwartz y Luna i Francesc Carreras i Candi, eds., Ajuntament de Barcelona, Barcelona, 1892, p. 53.

301 AHCG XV.4, lligall 1, llibre 3, sense numerar.

302 ACV, Calaix 9, pergamins del bisbe Ponç de Vilaró, 1304.

303 Ignasi PUIG, Pariatges entre els abats de Gerri i els comtes del Pallars Sobirà $i$ de Foix, dels segles XIX i XV, «Urgellia», 2 (La Seu d'Urgell, 1979), pp. 350-351.

304 ACA, Cancelleria, reg. 1782, fols. 31r-47r.

305 Flocel SABATÉ, Font oral i font escrita per a una nova Vilaclara, «Vilaclara de Castellfollit del Boix (el Bages). Un assentament rural de l'antiguitat tardana», Joan Enrich, Jordi Enrich i Lluís Pedraza, dirs., Arqueoanoia edicions, Igualada, 1995, pp. 129-131. 
vescomte de Cardona per haver autoritzat el mercat de Calaf sense permís del monarca ${ }^{306}$, conflicte ben revelador del joc de poder en tant que aquest mateix vescomte havia estat procurador de Catalunya. Actuacions d'aquesta mena es solen dur a terme en un contacte permanent amb el sobirà, tal com també succeeix a la darreria del regnat de Pere III, quan des de l'àmbit reial s'invoca la capacitat judicial sobre l'estament nobiliari o fins i tot l'usatge Simili modo per a intimidar determinats barons. En procedir així a Anglesola el $1379^{307}$, es palesa, però, la voluntat de l'oficial governatiu i del monarca per assolir arranjaments pecuniaris mitjançant remissions generals.

De fet, des d'aquest costat de la societat, les actuacions del governador a la sortida del segle XIV també són acusades d'estar guiades per un afany recaptador. Alhora, les respectives capacitats d'acord amb l'estat de la jurisdicció enterboleixen les discussions, bé que l'alt oficial reial es justifica mitjançant invocar l'afany per preservar els àmbits d'exclusiva jurisdicció reial. És, per exemple, el greuge que el monestir de Poblet exposa a les corts el 1375 contra el governador de Catalunya, perquè en haver sortit el sometent de Tarrés, per a encalçar un veí que havia comès unes nafres, fins a Vimbodí, malgrat incloure's ambdós indrets dins del domini del monestir, el governador féu pendre e tenir preses en Muntblanc tots los homens del dit loch de Terrers no solament aquells qui foren al so mas encara aquells qui eren absents del dit loch, dient que havien feyt procés de sometent e que eren exits del terme del dit loch e axí que havien greument delinquit, tot contradient al mateix monarca en al.legar que ningú pogués revocar negun procés que ell faes, raó per la que sols els deslliurà després de percebre cent florins ${ }^{308}$.

Alhora, el protagonisme assolit per un governador que assumeix la màxima representació sobre el conjunt del país topa amb els criteris d'una societat estamental, en la que els grans nobles exigeixen la consideració superior que els pertoca. Significativament, en l'interregne de 1410-1412 és el sector nobiliari qui articula les queixes contra el poder del governador, recorrent fins $i$ tot a arguments romanistes per a discutir-li la capacitat de convocar el parlament - no.s pertanya convocar sinó a prínce $\mathrm{p}^{309}$-, traslladar-lo $\mathrm{l}^{310}$ o intervenir-hi ${ }^{311}$, a més de si podia lo governador en dit cas vacant las veguerías o batllias, fer veguers y batlles ${ }^{312}$.

306 ACA, Cancelleria, reg. 245, fol. 38r.

307 ACA, Cancelleria, "Papeles por incorporar», 1379, sense numerar.

308 Cortes de Catalunya, "Cortes de los antiguos reinos de Aragón y de Valencia y Principado de Cataluña", III, Real Academia de la Historia, 1900, p. 316.

309 Cortes de Catalunya, "Cortes de los Antiguos Reinos de Aragón y Valencia y Principado de Cataluña", VII, Real Academia de la Historia, Madrid, 1903, p. 45.

310 Cortes de Catalunya, "Cortes de los Antiguos Reinos de Aragón y Valencia y Principado de Cataluña», VII, Real Academia de la Historia, Madrid, 1903, pp. 43-46.

311 Cortes de Catalunya, "Cortes de los Antiguos Reinos de Aragón y Valencia y Principado de Cataluña", IX, Real Academia de la Historia, Madrid, 1905, pp. 344.

312 Ceremonial dels Magnifichs Consellers y Regiment de la Ciutat de Barcelona, II. Francesch Carreras y Candi y Bartomeu Gunyalons y Bou, eds., Ajuntament de Barcelona, Barcelona, 1913, p. 139. 


\section{EVOLUCIÓ DE L'OFICI GOVERNATIU A LA SORTIDA DE L'EDAT MITJANA}

A la darreria del segle XIV la cort governativa manté una elevada activitat, tant atenent qüestions procedents de corts jurisdiccionals reials d'arreu de Catalunya ${ }^{313}$ com acollint nombroses obligacions o manaments ${ }^{314} \mathrm{i}$ atorgant remissions $\mathrm{i}$ guiatges ${ }^{315}$. Alhora, titulars de forta personalitat com, sobretot, Ramon Alemany de Cervelló, imposen una gran capacitat d'influència política, d'intervenció judicial i d'aplicació de mesures de caire extraordinari. Són raons que enalteixen la institució en el panorama públic alhora, però, que la fan veure amb malfiança, a partir de motius diferents, pels poders municipals i baronial. De fet, malgrat la preeminència palmatòria del governador, no serà pas aquest qui representi el monarca en els casos greus que es succeeixen a finals del segle XIV. En aquests moments, la corona no pot encarar la gravetat assolida pels conflictes de bàndols o per interseccions entre feudalitat $i$ capitalitats urbanes ni a través dels seus oficials districtuals ordinaris, considerats com massa mediatitzats pels poders locals, ni mitjançant el superior, prou contrariat pels vectors de força de la societat. El monarca haurà de recórrer a procuradors o lloctinents especials que actuin loco et vice nostris a Vic el 1388, al Lluçanès el 1398 i a Lleida el $1401^{316}$, en unes actuacions que consoliden les intervencions extraordinàries, ja el 1398, in viceregium pro nobis in toto Cathalonia principatu ${ }^{317}$. Significativament, a Vic ${ }^{318}$ el virrei Pere de Llívia entre 1402 i $1405^{319}$ actua de manera plena -amb el seu assessor ${ }^{320}$ i quan cal representat pel propi lloctinent ${ }^{321}$ - a partir del procés iniciat pel governador $\mathrm{i}$ atorgant un paper merament executiu al veguer ${ }^{322}$. Assumint així la plena delegació reial en afers determinats sobre espais concrets, la figura virreinal es reprèn en el segle XV per a intervencions concretes ${ }^{323}$ en llocs com Berga el 1410 o de nou Vic el $1426^{324}$.

313 ACA. Diversos. Fons Institucionals. Governació General de Catalunya, reg. 1, fols. 1r-144v.

314 ACA. Diversos. Fons Institucionals. Governació General de Catalunya, reg. 3, fols. 1r-148v.

315 ACA. Diversos. Fons Institucionals. Governació General de Catalunya, reg. 4, fols. 1r-149v.

316 Flocel SABATÉ, El veguer a Catalunya. Anàlisi del funcionament de la jurisdicció reial al segle XIV, tesi doctoral, Universitat de Barcelona, 1993, pp. 1717-1721.

317 ACA, Cancelleria, reg. 2217 , fols. $43 v-45 r$.

318 CF, liber consiliarium 1400-1402, sense numerar; 1400-1403, sense numerar; 1400-1404, sense numerar.

319 Eduard JUNYENT, Intervencions reials en la constitució del consell de Vic (1313-1350), «Estudis d'Història Medieval», IV (Barcelona, 1971), pp. 65-67.

320 AVV, lligall de registres 28 , plec 1402-1403, sense numerar.

321 AHMV, llibre de Privilegis XXV, pergamí 151.

322 AHMV, llibre de Privilegis IV, 67.

323 La mateixa innovació, dins del Principat, del virrei per als conflictes del Lluçanès i de Vic (Flocel SABATÉ, El veguer a Catalunya. Anàlisi del funcionament de la jurisdicció reial al segle XIV, tesi doctoral, Universitat de Barcelona, 1993, pp. 1718-1719) és coetània a l'actuació, en el mateix 1398, d'Hug d'Anglesola a Mallorca com a cavaller del molt alt senyor rey, conseller e camerlench $\theta$ per lo dit senyor viçrey en lo regne de Mallorques e islles de aquell (ACA, Cancelleria, reg. 2356, fol. 1v).

324 Jesús LALINDE, Virreyes y lugartenientes medievales en la Corona de Aragón, "Cuadernos de Historia de España», XXXI-XXXII (Buenos Aires, 1960), pp. 125-154. 
D'aquesta manera, la governació evidencia una redimensió del propi espai, tant pel retall en la confiança del monarca com per la malfiança en el contacte amb els efectius àmbits de poder de la societa ${ }^{325}$. La pressió dels municipis és ben evident: el mateix governador de Catalunya, en ser assistit per un adjunt - adiuncto-durant l'interregne, ha de col.locar en aquesta posició a un membre de la burgesia barcelonesa ${ }^{326}$. El poder municipal, precisament, anirà trabant l'actuació del governador mitjançant les corts generals, que el 1419 li impediran actuar judicialment on estigui procedint la cort reia ${ }^{327}$, el 1431 protestaran la seva extracció de causes ${ }^{328}$, el $1437 \mathrm{li}$ recalcaran que ha de jurar i respectar les Constitucions, com ja s'havia acordat el $1413^{329}$, el 1469 l'acusaran de nou per manca de diligència en retornar les causes als ordinaris en sortir de la demarcación ${ }^{330}$, el 1493 li imposaran jurar els privilegis locals de cada població i vegueria en entrar-hi331 i el 1503 advertiran dels abusos en l'avocació, que el 1495 s'ha pretés legislar per a les causes menors de 10 o 20 lliures dis de la demarcación ${ }^{332}$. L'elevada activitat de la cort governativa la converteix en una maquinària estable i pràcticament permanent, cosa que indisposa la ciutat de Barcelona, que li recalca que sols té raó de ser servint al governador i per tant en absència d'aquest no

325 Dins del mateix àmbit reial es detecten algunes banalitzacions de la terminologia, com els capitans que el 1381 reben l'ofici com a capitaneum, rectorem et gubernatorem de ville (...) et vicarie eiusdem (ACA, Cancelleria, reg. 2014, fol. 38r-v).

326 En Ffrancesch Burguès com a adjunct del noble mossèn lo Governador (Cortes de Catalunya, "Cortes de los Antiguos Reinos de Aragón y Valencia y Principado de Cataluña», VIII, Real Academia de la Historia, Madrid, 1904, pp. 324-325).

327 Cortes de Catalunya, "Cortes de los Antiguos Reinos de Aragón y Valencia y Principado de Cataluña", XII, Real Academia de la Historia, Madrid, 1908, pp. 308-309; Cortes de Catalunya, "Cortes de los Antiguos Reinos de Aragón y Valencia y Principado de Cataluña», XVI, Real Academia de la Historia, Madrid, 1912, p. 53.

328 Cortes de Catalunya, "Cortes de los Antiguos Reinos de Aragón y Valencia y Principado de Cataluña», XVIII, Real Academia de la Historia, Madrid, 1913, pp. 396-397.

329 Constitucions y altres drets de Cathalunya, llibre I, títol XXVII, VI-VII (Joan Pau Martí y Joseph Llopis, estampers, Barcelona, 1704; ed. facsímil, Departament de Justícia de la Generalitat de Catalunya, 1995, llibre I, p. 104).

330 Cortes de Catalunya, "Cortes de los Antiguos Reinos de Aragón y Valencia y Principado de Cataluña», XXIV, Real Academia de la Historia, Madrid, 1918, p. 100.

331 Constitucions y altres drets de Cathalunya, Ilibre I, títol XXVII, VIIII (Joan Pau Martí y Joseph Llopis, estampers, Barcelona, 1704; ed. facsímil, Departament de Justícia de la Generalitat de Catalunya, 1995, llibre I, p. 104).

332 Jesús LALINDE, La gobernació general en la Corona de Aragón, Institución «Fernando el Católico», Zaragoza, 1963, p. 331. 
pot funcionar, tal i com es retreu, arran de significatives topades concretes, a les corts de $1431^{333}, 1476^{334}, 1479^{335} \mathrm{i}$, encara, $1481^{336}$.

Institucionalment, les absències reials consoliden una peça superior a totes en la representació reial, la lloctinència ${ }^{337}$, prou perfilada pel rei Martí -el 1401 designa la seva esposa com a generalem locumtenens vicesque nostras gerentem ${ }^{338}$ - i, sobretot, per la llarga absència napolitana del Magnànim entre 1432 i 1458. Les pressions de les veritables forces, precisament, fan que el poder municipal encapçalat per Barcelona forci al monarca a atorgar el càrrec, entre 1436 i 1453 a la reina Maria i no pas a l'infant Joan, considerat més dur que no pas la seva cunyada ${ }^{339}$, cosa que, durant aquest període, col.loca Catalunya sota el tractament específic de la sereníssima reyna dona Maria com a loctinent general del sereníssimo Rey sennor y marit seu $u^{30}$.

La consolidació de la lloctinència arreu del país manté la figura de la governació general i el seu portantveus de governador de Cathalunya - generali nostro gubernatori eiusque vicesgerenti in principatu Catalonie escriu el lloctinent reial el $1459^{341}$, prou caracteritzat com a governador de Catalunya. Aquest manté tant la intensa activitat ordinària de la pròpia cort com un destacat paper polític, prou personificat en Galceran de Requesens, al front de l'ofici entre 1443 i 1461. Significativament, el rei tracta de manera directa amb el loctinent general, el governador de Cathalunya ${ }^{342} i$ encara el govern local de Barcelona ${ }^{343}$, de la mateixa manera que rep representants dels tres a

333 Cortes de Catalunya, «Cortes de los Antiguos Reinos de Aragón y Valencia y Principado de Cataluña», XVIII, Real Academia de la Historia, Madrid, 1913, p. 397.

334 Ceremonial dels Magnífichs Consellers y Regiment de la Ciutat de Barcelona, II, Francesch Carreras y Candi y Bartomeu Gunyalons y Bou, eds., Ajuntament de Barcelona, Barcelona, 1913, p. 143.

335 Ceremonial dels Magnifichs Consellers y Regiment de la Ciutat de Barcelona, II, Francesch Carreras y Candi y Bartomeu Gunyalons y Bou, eds., Ajuntament de Barcelona, Barcelona, 1913, p. 138-139.

336 Constitucions y altres drets de Cathalunya, llibre I, títol XXVII, VIII (Joan Pau Marti y Joseph Llopis, estampers, Barcelona, 1704; ed. facsímil, Departament de Justícia de la Generalitat de Catalunya, 1995, llibre I, p. 104).

337 Jesús LALINDE, Virreyes y lugartenientes medievales en la Corona de Aragón, "Cuadernos de Historia de España», XXX-XXXII (Buenos Aires, 1960), pp. 120-121.

338 ACA, Cancelleria reg. 2223, fol. 73 r.

339 Alan RYDER, Alfonso el Magnánimo, rey de Aragón, Nápoles y Sicilia (1396-1458), Edicions Alfons el Magnànim, València, 1992, p. 231.

340 Ramón FERNANDEZ DE TIRSO y SEMPER, El "Llibre Ferrat» de Livia, Universidad de Alicante, Alicante, 1984, p. 26; Cebrià BARAUT, El Llibre Ferrat. Privilegis i ordinacions de la vila de Llívia, Patronat del Museu de Llívia, Llívia, 1985, p. 31, com exemple de l'ús d'aquesta expressió.

341 Antonio M ${ }^{a}$ ARAGO - Mercedes COSTA, Privilegios reales concedidos a la ciudad de Barcelona, Colección de Documentos Inéditos del Archivo de la Corona de Aragón, XLIII, Archivo de la Corona de Aragón, Barcelona, 1971, p. 257.

342 José Maria MADURELL MARIMON, Mensajeros barceloneses en la corte de Nápoles de Alfonso $V$ de Aragón, 1435-1458, CSIC, Barcelona, 1963, p. 612.

343 José Maria MADURELL MARIMON, Mensajeros barceloneses en la corte de Nápoles de Alfonso $V$ de Aragón, 1435-1458, CSIC, Barcelona, 1963, pp. 501-502. 
la cort napolitana. Alfons el Magnànim palesa un clamorós suport a un governador que centra l'activitat en un pugna contra el govern patrici de Barcelona. Sense recança, el monarca atorga a lo magnifich e amat conseller e camerlench nostre mossèn Galceran de Requesens, governador de aqueix principat de Cathalunya ${ }^{344}$ un ostentós tracte en rebre'l el 1455 a Nàpols ${ }^{345}$ i l'avala davant de la ciutat ${ }^{346}$. La tibantor entre el governador i la capital catalana, en realitat, evidencia la fractura de l'exercici jurisdiccional reial, amb una cort governativa que invocant la corona col.lideix reiteradament amb la del veguer recolzada pel municipi en episodis com els viscuts el $1446 \mathrm{i}$ incloent la detenció del sotsveguer el 1447 o les contradiccions en guiatges patides el 1459. I destaca, alhora, la identificació del governador amb el manteniment de l'ordre, amb la certa paradoxa que els dirigents locals alhora enfrontats demanen la seva presència per a garantir la pau, com el $1449^{347}$ o el 1452, quan sol.liciten a la reina i lloctinent general la presència del substitut del governador ${ }^{348}$-Petrus de Ortafano, miles, serenissimi domini regis consiliarius et pro eodem domino regens officium gubernationis Cathalonie generalis in absencia multum honorabilis Galcerandi de Requesens militi gubernatoris Cathalonie Generalis ${ }^{349}$ - tot reiterant així el caire imprescindible d'aquest. El pols entre el govern patrici barceloní i el governador Requesens suma tots els trets de les tensions jurisdiccionals: el privilegi reial que el 1444 limita l'estada a la ciutat del governador, l'assalt a Barcelona el 1350 pels homes de Torrelles que després es refugien a Molins de Rei, possessió del governador ${ }^{350}$, la intercessió reial perquè el governador entre dins la dita ciutat e en aquella lo permatan star fins haguen conclusió deguda los dits negocis ${ }^{351}$ i la definitiva revocació de 1351 de les limitacions imposades

344 José Maria MADURELL MARIMON, Mensajeros barceloneses en la corte de Nápoles de Alfonso $V$ de Aragón, 1435-1458, CSIC, Barcelona, 1963, p. 507.

345 Lo senyor rey l'a rebut molt bé e ab gran cara, eli fa gran festa, och li ha feta una singularíssima honor, tal, que encara que despuys hic som, no havem vist l'age feta a duch, comte ni baró, ne a home que hinch sia stat, car hali fet un convit, sol per amor de ell, al Castell de l'Ou, e aquí l'a convidat a dinar e sopar, en fastagar-lo tot lo jorn, mostrant-ll tant cara, com a una persona conjuncta s'en pot mostrar. Och, l'a fet seure en sa taula que fins aci no havem vist ho hage fet de negú, si donchs embaxadors de reys, o de aquestes comunitats d'Itàlia no eran, aquells havem vist ha convidats alscunes vegades a dinar, però mas no a sopar e seyen en sa taula, mas altres duchs, prínceps, comptes $e$ barons no's havem vists seure en sa taula, si bé.ls ha convidats per amor d'ell (José Maria MADURELL MARIMON, Mensajeros barceloneses en la corte de Nápoles de Alfonso $V$ de Aragón, 1435-1458, CSIC, Barcelona, 1963, p. 503).

346 José Maria MADURELL MARIMON, Mensajeros barceloneses en la corte de Nápoles de Alfonso V de Aragón, 1435-1458, CSIC, Barcelona, 1963, p. 507.

347 Ceremonial dels Magnífichs Consellers y Regiment de la Ciutat de Barcelona, II, Francesc Carreras y Candi - Bartomeu Gunyalons y Bou, Ajuntament de Barcelona. Barcelona, 1913, p. 137140.

348 AHCB, II-8, fols. 61v-62r.

349 ACA, Diversos. Fons institucionals. Governavació General de Catalunya, reg. 18, fol. $1 \mathrm{r}$.

350 Carme BATLLE, La ideología de la "Busca", "Estudios de Historia Moderna", V (Barcelona, 1955), pp. 174-175.

351 AHCB IX-A, lletra reial núm. 624. 
al governador, tot palesant les respectives capacitats de pressió davant del monar$\mathrm{ca}^{352}$.

De fet, el governador esdevé el principal avalador i sostenidor de la causa buscaire ${ }^{353}$, que arrenca el poder a la Biga entre 1453 i $1460^{354}$, anys en els que no deixarà d'exercir una permanent ingerència. En aquest context, el governador incideix fortament sobre els oficials reials a Barcelona, col.locant en posició incòmode tant al batlle com al veguer. Safont contraposa la seva facilitat per a concedir guiatges als propis a la voluntat d'estendre la sospita de la corrupció sobre els magistrats precedents en manar al veguer i al batlle que no guiassen algun ciutadà honrat qui fins aci fos stat conseller, tauler, clavari, mostaçaf o altre qualsevol qui hagués tengut ofici de la ciutat ${ }^{p 55}$. Aquest alt poder gairebé omnímode exercit ara pel governador, amb actuacions tendencioses i partidistes segons els seus contraris ${ }^{356} i$ amb decisions com la detenció i cessament del batlle de Barcelona el $1450^{357}$ o la destitució del veguer obtinguda del lloctinent general el 1457, no rau en el contingut de la institució sinó en la conjuntura concreta, per la que ell mateix entre 1453 i 1454 esdevé lloctinent general resistint les fortes queixes municipals. Per això, a partir de 1454, manté, amb el suport de buscaires i remenses, una concordança política amb la lloctinència general del germà del Magnànim, el rei de Navarra, cosa que no deixa de llevar-li protagonisme en favor del lloctinent ${ }^{358}$.

Aquest aferma la posició preeminent. A ell s'adrecen els diferents governs locals i els poderosos barons en cercar suport pels diferents afers sorgits entorn de privilegis, nomenament $i$ actuació d'oficials, tensions internes o qualsevol altre assumpte de govern, així com la mateixa línia ha estat la usual i ordinària en el tracte amb els oficials reials districtuals ${ }^{359}$. Tanmateix el governador serva els indicadors de poder. En les

\section{ACA, Cancelleria, Fons Barcelona, pergamí 295.}

353 En realidad, el pueblo sólo le obedecía a él, por eso el rey Alfonso y sus esposa le mantuvieron en el cargo de lugarteniente de Cataluña después de notificarle su destitución, por el temor de una sublevación en masa como la de Mallorca (Carme BATLLE, La ideología de la "Busca», "Estudios de Historia Moderna", $V$ [Barcelona, 1955], pp. 174-175).

354 Segons Carme Batlle, en el triomf de la Busca hi juga un paper bàsic el governador, perquè el partido popular constituia un grupo muy numeroso e inexperto, sin influencias ni riquezas, excepto algunos moderados, y si consiguió oponerse al poderoso patriciado, fue gracias a la decidida protecció de un hombre de confianza de Alfonso el Magnánimo, el caballero Galceran de Requesens (Carme BATLLE, Barcelona a mediados del siglo XV, Ediciones El Albir, Barcelona, 1976, p. 18).

355 Josep Maria SANS i TRAVÉ, Dietari o Libre de Jornades (1411-1484), Fundació Noguera, Barcelona, 1992, pp. 80-81.

356 Josep Maria SANS i TRAVÉ, Introducció, «Dietari o Llibre de Jornades (1411-1484)», Fundació Noguera, Barcelona, 1992, pp. LXIX-LXXIII.

357 Ceremonial dels Magnifichs Consellers y Regiment de la Ciutat de Barcelona, Il, Francesc Carreras y Candi y Bartomeu Gunyalons y Bou, Ajuntament de Barcelona. Barcelona, 1913, p. 138.

358 Jaume VICENS VIVES, Els Trastàmares (segle XV), Editorial Vicens Vives, Barcelona, 1988, pp. $163-165$.

359 Gabriel CASTELLA i RAICH, Una carta de la reina María de Aragón al subveguer de lgualada, "l Asamblea Intercomarcal del Penedès y Conca d'Odena", Martorell, 1950, pp. 161-165, per exemple. 
vigílies de la mort d'Alfons $V$, com exemple clar, és ell qui escriu als municipis i els personatges que considera adient per a demanar oracions perquè el sobirà té malaltia de terçana bé havia $X V$ jorns i demanant oracions ${ }^{360}$, alhora que tracta la qüestió tot fent colloqui ab el bisbe de Vic, Canceller, els Consellers de la Ciutat de Barcelona, deputats de Cathalunya $e$ ab el conseller i vicecanceller, Johan Pagès e ab altres del consell del dit senyor ${ }^{261}$. El mateix Galceran de Requesens pot consolidar la fortuna familiar gràcies a l'ofici que ja havia detentat el seu pare i que rebrà, posteriorment, el seu fill.

Si bé els episodis viscuts entorn de la primera ciutat catalana, per la seva iridescència, han captat pràcticament tota l'atenció historiogràfica sobre aquest període de la governació, el cert és que coetàniament la cort governativa manté el seu elevat ritme de treball en els diferents nivells. Durant tot aaquest període el governador ha intervingut a totes les zones de jurisdicció reial d'arreu de Catalunya, apaivagant els bàndols de Vic, atorgant remissions a les demarcacions de la diòcesi de Girona, solucionant els problemes de Cervera, acompanyant la reina a Ciutadilla $\mathrm{i}$ atentent les problemàtiques de Piera, Manresa, Berga, Santes Creus... i un llarg etcètera que cobreix tot el país ${ }^{362}$. És a dir, la governació es manté present arreu de Catalunya en l'acceptació de totes les queixes contra les actuacions dels ordinaris, alhora que continua registrant els manaments, seguretats, treves i paus finals ${ }^{363}$.

L'actuació governativa s'identifica amb la consolidació preeminent de la jurisdicció reial en els seus trets emblemàtiques de garant de l'exercici judicial i de l'ordre públic, amb la paradoxa que aquesta proclama topa reiteradament amb uns governs locals que també invoquen ésser garants de la jurisdicció reial, amparant-se en els oficials ordinaris. Es el que s'exemplifica a Girona el 1446, quan el nou sotsveguer, en demanda de suport contra el rebuig del municipi i del veguer, s'adreça al governador, el qual, a la recerca d'un oficial reial favorable, exigeix la intervenció del jutge d'apel.lacions gironí en tant que, com siats official reyal, per deure del qual offici sou obligat e us devets retre prompte de fer, tenir, complir e exequtar los manaments reyals si per altres officials reyals ere temptat fer lo contrar ${ }^{364}$. La mateixa invocació de les regalies empara una actuació governativa que confesa recolzar el poder de la corona si cal oposant-se a les capacitats preteses pels propis oficials reials, tal com el 1446 el governador d Catalunya imposa al batlle de Moià, tot recordant-li que ten solament siats mer exequtor en tal negoci, de la qual execució vós no haureu a tenir taula com tal procés de regalia ab totes ses dependències sia mera regalia del príncep e fore dels termes de les constitucions de Cathalunya e lo qual procés fins a final exequció se fa en nom e veu e en persona de la dita senyora reyna ${ }^{365}$.

360 ACA, Diversos. Fons institucionals. Governació General de Catalunya, reg. 19, fols. 23v-24r.

361 ACA, Diversos. Fons institucionals. Governació General de Catalunya, reg. 19, fol. 24r.

362 ACA, Diversos. Fons Institucionals. Governació General de Catalunya, reg. 18-20, per exemple.

363 ACA. Diversos. Fons institucionals. Governació General de Catalunya, regs. 12-21.

364 ACA, Diversos. Fons Institucionals. Governació General de Catalunya, reg. 18, fols. 46v-47r.

365 ACA, Diversos. Fons Institucionals. Governació General de Catalunya, reg. 18, fols. 45v-46r. 
Tots aquests trets es mantenen en assolir el tron un Joan II que no es descuïda de designar el lloc superior de lo primogènit e loctinent general, fins i tot quan en la minoritat de Ferran en la lloctinència caldrà obeir la reina ut tutrix. La imbricació reial del governador general marcarà la figura durant la guerra civil. La pretensió de mantenir l'activitat ordinària arreu de Catalunya es cenyirà en la pràctica a les zones sota control de Joan II. El caire bèl.lic impregnarà de ple la mateixa imatge del governador. Precisament, el 1473, mostrant-se ben adaptat a l'estada lleidatana, el titular de l'ofici és, alhora lo governador de Cathalunya e capità de la ciutat e vegueria de Leyda ${ }^{366}$.

Mentrestant, als comtats de Rosselló i Cerdanya, el governador ha mantingut l'elevada representació efectiva. Fins i tot, en el període de domini francès (1462-1493) es reitera la suma dels oficis de governador $i$ de capità general $i$, encara més, la delegació d'aquest en un lloctinent que moltes vegades hi afegeix la batllia de Perpinyà ${ }^{367}$. Aquesta barreja accentua una concentració de poder fàcilment popularitzable arran de la centralització de decisions polítiques i administratives. La visió comuna prioritza la imatge governativa, entenent la de capità com afegida: és 10 dit noble loctinent de governador e batle.

En cloure el segle XV, sota Ferran II, la figura governativa es manté allunyada de les altes gestions, en les que la lloctinència no sols manté una actuació destaca amb l'infant Enric, duc de Sogorb i comte d'Empúries -infante nuestro muy caro y muy amado primo e lugarteniente general - , sinó que s'aferma en l'organigrama institucional mitjançant la designació d'un lloctinent per a cada territori. Alhora, el lligam establert entre el lloctinent general i l'audiència ara afermada absorbeixen una elevada actuació judicial i fins i tot els consellers de Barcelona el 1486 aconsegueixen precedir en el protocol al governador ${ }^{368}$. Tot plegat permet entendre-hi una situació decadent per aquest ${ }^{369}$ per bé que, pròpiament, evidencia la consolidació de la seva redefinició.

Certament, la governació clou els segles medievals pletòrica d'activitat en la contenció de l'ordre públic, molt directament a Barcelona, on reitera les crides que han de pacificar la societat i on, ara, més que guiatges, es succeeixen les revocacions d'aquests. Alhora, manté l'activitat de la cort com a garant de les diverses obligacions personals $\mathrm{i}$ intervé a tot arreu on es formulen queixes al comportament dels ordinaris, evidenciant així una plena identificació amb el perfil territorial català ${ }^{370}$. Aquesta mateixa activitat d'ordre públic definirà l'ofici governatiu en els posteriors temps moderns ${ }^{371}$, tot

366 ACA, Diversos. Fons Institucionals. Governació General de Catalunya, reg. 22, fol. 1v, entre altres.

367 ADPO 1B-346, fol. 165v.

368 Ceremonial dels Magnifichs Consellers y Regiment de la Ciutat de Barcelona, II, Francesch Carreras y Candi y Bartomeu Gunyalons y Bou, eds., Ajuntament de Barcelona, Barcelona, 1913, p. 139.

369 Miguel Angel LADERO, El ejercicio del poder real en la Corona de Aragón: Instituciones e instrumentos de gobierno (siglos XIV y XV), «En la España Medieval», 17 (Madrid, 1994), p. 53.

370 ACA, Diversos. Fons institucionals. Governació General de Catalunya, reg. 29, fol. 1 r-241v.

371 Juan BENEYTO, Las instituciones de los países de la Corona de Aragón en el siglo XVI, "VIII Congreso de Historia de la Corona de Aragón (Valencia, 1967)», vol. I, València, 1973, p. 160. 
servant la malfiança amb el poder municipal, sobretot el de Barcelona ${ }^{372}$, obligant-lo a seguir la terra ${ }^{373} i$ identificant-lo, un pèl encarcaradament, amb el perfil físic i institucional català ${ }^{374}$, en una posició apartada de l'alta esfera política, ara centrada en la figura virreinal mentre altres institucions reben l'encreuament dels veritables vectors de força de la societat catalana ${ }^{375}$.

372 Ceremonial dels Magnifichs Consellers y Regiment de la Ciutat de Barcelona. Rúbriques de Bruniquer, V, Joaquim Carreras i Candi - Bartomeu Gunyalons i Bou, eds. Ajuntament de Barcelona, Barcelona, 1916, p. 143.

373 Joaquim NADAL, Catalunya dins l'imperi hispànic: l'articulació institucional i el seu funcionament, "Història de Catalunya», IV, Josep M. Salrach, dir., Salvat editores, Barcelona, 1978, p. 9.

374 Jesús LALINDE, La gobernación general en la Corona de Aragón, Institución «Fernando el Católico», Zaragoza, 1963, p. 345.

375 Joan Lluís PALOS, Catalunya a I'Imperi dels Austria, Pages editors, Lleida, 1994, pp. 597504. 